\title{
REVEGETATION TRENDS AND LESSONS AT TWO MONTANA COAL MINES BASED ON 20 YEARS OF MONITORING ${ }^{1}$
}

\author{
R. A. Prodgers ${ }^{2}$
}

Abstract: Bighorn Environmental Sciences monitored revegetation at Spring Creek Coal Mine (SCCM) and Decker Coal Mine (DCM) in semiarid southcentral Montana for 20 years using consistent transect locations and methods. Measurements include canopy coverage, air-dried peak standing crop (PSC), and shrub density. About 30 SCCM fields were old enough to evaluate temporal trends. Findings include:

- Ten years after seeding, post-mine perennial productivity and canopy coverage were trending upward and exceeded both performance standards and pre-mine vegetation.

- Shrub density declined in about $4 / 5 \mathrm{~s}$ of fields. Meeting the shrub density standard of $5,740 /$ ha for wildlife habitat, the primary post-mine land use, is a major revegetation challenge.

- Rosana western wheatgrass tripled in relative cover by the conclusion of monitoring. It combines environmental suitability and vigorous rhizomatous spread. Introduced sheep fescue spread even more abundantly, quadrupling relative cover from the early years to one decade or more later, also spreading to adjacent fields.

- Cheatgrass, which replaces annual forb weeds in unsatisfactory seedings, showed no net temporal trend.

- The explosion of the first-year kochia impairs seeding success through interference competition. Prevention requires mine-wide effort. Seeding into annual weeds or litter has not worked, requiring chemical weed control and litter removal before interseeding. The first seeding opportunity is the best.

- Shrub seedings are far more successful on suitable spoil than on topsoil. However, some spoil meeting the chemical-physical suitability criteria does not support satisfactory revegetation. Scoria can be a fine shrub and diversity substrate or disappointing.

- Heavy-seeded Chenopod shrubs can be established through drill seeding even among vigorous, competitive grasses.

- Light-seeded sagebrush establishes best when seeded apart from the heavy-seeded plants.

- The most prevalent contribution of direct-haul coversoil to revegetation is weeds, not native perennials.

Additional Key Words: performance standards, bond release, seeding shrubs, revegetation substrates, plant litter, seeding techniques, interseeding, pre-emergent herbicides.

1 Oral paper presented at the 2016 National Meeting of the American Society of Mining and Reclamation, Spokane, WA Reclaiming the West June 4-9, 2016. Published by ASMR, 1305 Weathervane Dr., Champaign, IL 61821.

${ }^{2}$ Richard A. Prodgers, Plant Ecologist, Bighorn Environmental Sciences, Dillon, MT 59725. Journal American Society of Mining and Reclamation, 2016 Volume 5, Issue 1 pp 111 - 146 DOI: http://doi.org/10.21000/JASMR16010111 


\section{Mine Setting and Revegetation Objectives}

Introduction

The first part of this paper summarizes 20+ years of revegetation monitoring data at SCCM. This forms the basis for trend evaluation. Those data were augmented by monitoring at DCM, which lacks the field-rotation monitoring of SCCM but still provides important lessons. The second part of this paper explains how the two mines tackle two of the main revegetation challenges: 1) preventing or overcoming first-year kochia infestations, and 2) providing the shrub density necessary for bond release in areas designated as wildlife habitat.

Coal mine disturbance in Montana totals about 16,360 ha (40,400 acres or about 63 square miles) with about half of which received cover soil and were seeded (MDEQ, 2015). The two mines studied, Spring Creek Coal Mine (SCCM) and Decker Coal Mine (DCM), comprise about 4,900 ha (12,115 acres or 19 square miles) of disturbance. SCCM was granted Phase III bond release for 164 ha (406 acres) of revegetation in 2015 (Bond Release Package SL8).

Both coal mines are located in south-central Montana near Decker at an approximate elevation of 1,070 meters (3,500 feet). Climate is continental. Mean annual precipitation at SCCM for the 35 -year life of the mine is $27 \mathrm{~cm}$ (10.8 inches) and a bit higher at the adjacent DCM. The modal soil texture is a clay loam, but scoria typically has sandy loam texture and lots of rock fragments. Soil crusting can impede seed establishment.

SCCM revegetation is distinguished by several seedings in most fields using some of the nine major seed mixes. Fields may have up to three distinct substrates: 1) topsoil or "lift 1," the upper $15 \mathrm{~cm}$ [six inches]; 2) scoria; and 3) suitable spoil. Several seed mixes may be applied in a field, providing, in conjunction with different substrates, a mosaic of shrubby areas (wildlife habitat) and areas with fewer shrubs (grazing land).

In a semiarid climate, productivity and plant cover must be viewed within the context of precipitation, although the relationship is nonlinear. The 1980s were very dry, qualifying as arid (Table 1). The 1990 s were considerably wetter and the 2000 s more so. The precipitation regime has shifted from arid to semiarid. Most rain falls in May-June, which is the most influential season for the predominantly cool-season plants. 
Table 1. Precipitation trends at the Spring Creek Mine, 1981-2010.

\begin{tabular}{cccc}
\hline DECADE & MAY-JUNE & APRIL-JULY & ANNUAL \\
& $-\ldots \ldots \ldots$ & - & - \\
\hline $1981-1989$ & $7.4(2.9)$ & $11.4(4.5)$ & $21.3(8.4)$ \\
$1990-1999$ & $9.1(3.6)$ & $15.7(6.2)$ & $25.6(10.1)$ \\
$2000-2010$ & $10.9(4.3)$ & $17.3(6.8)$ & $31.5(12.4)$ \\
$2011-2015$ & $15.0(5.9)$ & $20.8(8.2)$ & $37.3(14.7)$ \\
\hline
\end{tabular}

Performance Parameters: Plant Cover, Peak Standing Crop, and Shrub Density

Compared to revegetation, pre-mine vegetation is diverse, unproductive, and frutescent. Based on three vegetation baseline inventories performed by me (South Fork Spring Creek, Carbone Ranch, and Pearson Creek) comprising a huge volume of data, Table 2 shows some basic characteristics of pre-mine vegetation.

Table 2. Pre-mine (baseline) vegetational attributes, SCCM.

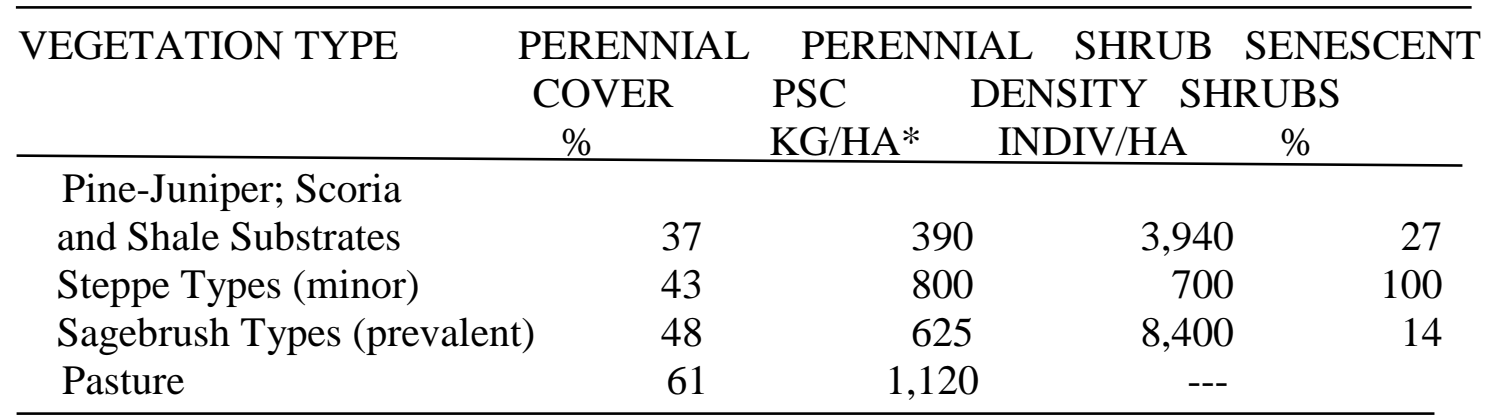

* Air-dried Peak Standing Crop, excluding tree productivity.

While diversity is mentioned in coal reclamation law ("diverse, effective, permanent"), it is not seriously considered when evaluating Montana coal revegetation, so I will not discuss it here except to say that revegetation cannot equal the diversity of pre-mine revegetation, which has more substrates and topographic diversity and a huge array of possible species operating on a vast timescale compared to revegetation.

Phase III bond release 10 or more years following seeding (or the last major propagation activity) is the goal of coal mine revegetation. SCCM currently has to meet the technical standards in Table 3 through weighted-average acreage of each land use. 
Table 3. Technical revegetation standards, SCCM. Revegetation must meet $90 \%$ of the standards with 0.1 Type 1 error.

\begin{tabular}{lccc}
\hline POSTMINE LAND USE & $\begin{array}{c}\text { SHRUB DENSITY } \\
\text { INDIV/HA }\end{array}$ & $\begin{array}{c}\text { PERENNIAL COVER } \\
\%\end{array}$ & $\begin{array}{c}\text { PEAK STANDING } \\
\text { CROP KG/HA }\end{array}$ \\
\hline GRAZING LAND & 1,110 & 50 & 775 \\
WILDLIFE HABITAT & 5,740 & 46 & none \\
PASTURELAND & none & 62 & 1,060 \\
\hline
\end{tabular}

These three post-reclamation land uses are prevalent: grazing land, pastureland, and wildlife habitat. At SCCM, the preponderance of revegetation intends to be wildlife habitat. Shrub density (Table 3) for wildlife habitat, the primary land use, is the most challenging aspect of revegetation.

Beyond shrub density, reestablishing sagebrush-steppe is desired at both mines. Wildlife habitat has no PSC standard and the plant cover standard is about $10 \%$ lower than for grazing land (Table 3), but if shrub density is inadequate for wildlife habitat, fields must meet cover and PSC standards for grazing land. Establishing sagebrush is best achieved in a relatively noncompetitive environment, but revegetation strategies intend to provide the shrub density required of wildlife habitat in conjunction with the cover and PSC necessary for grazing land.

Wyoming big sagebrush dominates the pre-mine landscape on most upland substrates. Premining densities were 8-9,000 shrubs/ha in the two big sagebrush types: big sagebrush/western wheatgrass and big sagebrush/bluebunch wheatgrass. (A list of common and scientific plant names concludes this article.) Silver and big sagebrush account for most of the 7,000 shrubs/ha in the silver sagebrush/western wheatgrass type. Shrub density was almost 5,000/ha in the open phase of the Ponderosa pine-Rocky Mountain juniper type. Fire exclusion and a century of heavy grazing (more previously than lately) are jointly responsible for the prevalence of woody plants in the current pre-mine landscape. On the more productive private lands near the mines, ranchers often replace it with introduced pastures for their greater productivity (Table 2).

Silver sagebrush is second among shrubs; it is found mainly in the lower drainages and sandy uplands. Black greasewood, winterfat, rubber rabbitbrush, skunkbush sumac, and prickly rose are locally important, but not at landscape scale. Another dozen minor shrub species are present. 


\section{Monitoring Methods}

Fields were monitored the first and second year after seeding and then every third year. Fields are contiguous areas where surface preparation and seeding were implemented at one time. A field may have several seedings, e.g., alluvial, upland, shrub mosaics, and special substrates.

\section{Canopy Coverage}

Canopy coverage (Daubenmire, 1959) is a two-dimensional ocular estimate. It reveals species composition while quantifying gross plant abundance two-dimensionally. Productivity is the gold standard quantifying plant-abundance parameters, but because of the greater number of plots per transect (seven for cover vs. three for PSC), canopy coverage can more accurately quantify plant abundance, although the third dimension, height, is missed.

Fifty-meter-long transects are located in each pit-area reclamation (PAR) field for the initial sampling one year after seeding. At this time, the field is typically weedy with perennial vegetational characteristics revealed only by close inspection, although seedling density can be measured to evaluate seeding effectiveness. While transect locations are subjectively chosen to represent different portions of fields, it would be impossible to bias them based on perennial vegetation appearance at this time. Fields were initially assigned two to four sample transects, but where different physiognomic types later manifested, additional transects are added up to a total five per field. Unfortunately, the uniform appearance of most new fields placed some transects crossing seeding boundaries.

Transect origins are indicated by green fence posts, terminating at red fence posts. One-halfsquare-meter, rectangular cover plots were sampled at meter locations 7, 14, 21, 28, 35, 42, and 48 on the left side of each transect; the same transects and plot locations were sampled each time a field was monitored.

Daubenmire's method of canopy-coverage estimation is the standard at the SCCM and DCM. Frame size is $1.0 \times 0.5$ meters. The frame is painted to indicate $1 \%, 5 \%, 10 \%, 15 \%, 25 \%$, and $50 \%$ areas. For each species, canopy coverage is estimated to the nearest percent up to $10 \%$ (insofar as possible), then by $5 \%$ increments. A value of $0.5 \%$ cover was used in data analysis where the coverage of a species was less than $1 \%$. Data are reported in terms of average canopy coverage, relative coverage, and frequency. The latter is the percentage of sample frames in which a species occurs. 
Total perennial plant cover was used to evaluate overall trends and compare to pre-mine vegetation and performance standards. Individual species trends used relative cover to discount the annual dynamic. Relative cover is each species' canopy coverage divided by total canopy coverage. Relative cover adds to $100 \%$.

Ground cover was estimated in terms of bare soil, coarse fragments ( $>2 \mathrm{~mm})$, and plant litter. Ground cover plus basal area of plants equals $100 \%$ of the sampled area. Exposed soil or rock under elevated plant canopies were counted as bare soil or rock.

\section{Peak Standing Crop}

Productivity is a fundamental attribute of plant communities. In sampling PSC, an attempt is made to harvest the annual increment of phytomass on a single date. Harvesting intends to occur at the time of peak accumulated phytomass, which is dependent upon phenologies of the dominant growth-forms. In an average year, the optimal sampling time for most perennial grasses at SCCM Creek is early August, and for some shrubs it is even later. Most annuals and biennials that are frequently important cure in June, dropping the seeds that can be an important component of weight. As a compromise, sampling occurs at both mines in late June through July.

Peak standing crop was sampled in $0.5 \mathrm{~m}^{2}$ rectangular plots, along the same transects as canopy coverage, but on the right side. At first, samples were harvested at random meter locations and later selected from remaining unsampled locations. Three plots were harvested per transect per year, six to 15 annual samples per sample year per field. Like other parameters, PSC was sampled every third year. Within a field, data from transects may be treated separately or combined according to substrate type and physiognomic types.

Measuring PSC by harvesting is fairly straightforward for herbs except for some succulents (e.g., yucca, cacti) that are insignificant in revegetation. Otherwise, herb stems are clipped approximately two $\mathrm{cm}$ from the ground except where a dense plant crown necessitates sampling higher (e.g., basin wildrye). When sampling woody species, all flowers and fruits within the sample plot were harvested along with a portion of the leaves ranging from all (e.g., skunkbush sumac), to about one-sixth (e.g., sagebrush). The annual increment of wood in stems and branches escapes measurement. Lacking a drying oven, harvested plant matter was placed in paper bags and left in a building where daily summer temperatures often exceed $120^{\circ} \mathrm{F}$ until fall, at which time they were weighed. 


\section{$\underline{\text { Shrub Density }}$}

Each transect was sampled for canopy coverage and PSC also served as the center of a 50- $\mathrm{m}^{2}-$ belt transect, along which shrubs were tallied to compute shrub density. Shrubs were counted if they were rooted within 0.5 meters of the tape. Measured shrubs were assigned to field-age classes and $25-\mathrm{cm}$ height classes. Shrub mosaics were inventoried differently, but those results are not presented here.

\section{$\underline{\text { Results }}$}

\section{$\underline{\text { Plant Cover and Composition }}$}

Once seeded perennials achieve mature stature, perennial plant cover in revegetation typically exceeds the pre-mine condition (Table 4). The uptick in cover in the final age class was most likely due to twice the mean May-June precipitation in 2010, when about half of the fields were last measured. It would be safer to conclude no sign of decline at the conclusion of the monitoring period.

Some fields buck every trend. PARs 1 and 1A, the first revegetation in a SCCM mined area, had $70 \%$ perennial ground cover the second year. This, however, was before the early profusion of annual weeds became standard in revegetation with attendant suppression of seeded perennials.

Table 4. Temporal trends in perennial canopy coverage, pre-mine cover (shrub-steppe), and the performance standard for grazing land, SCCM.

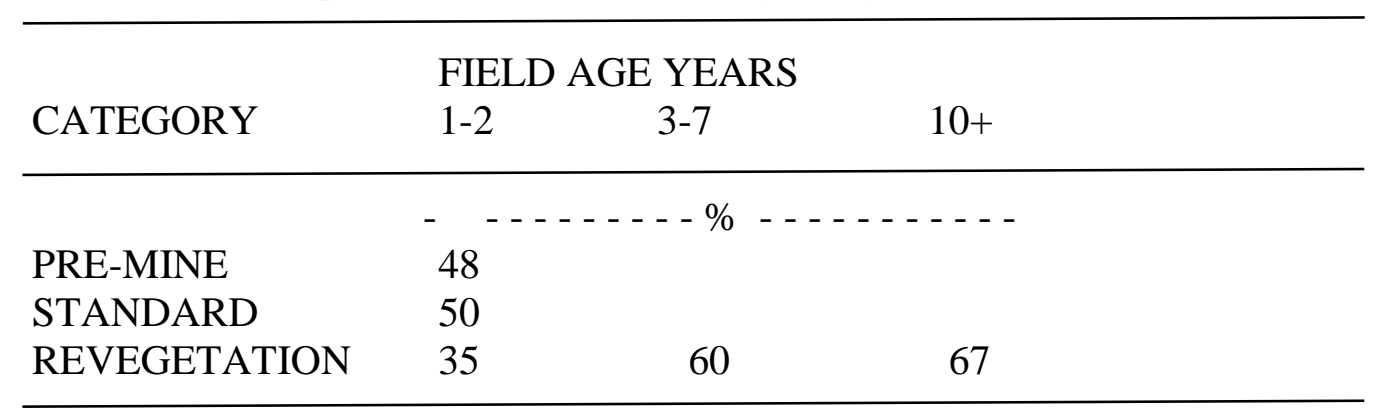

Whereas plant cover in revegetation exceeds pre-mine, the amount of bare ground and especially rock fragments is much lower in revegetation (Table 5). For this comparison, I used revegetation monitoring data from 2009-10 ( $\mathrm{n}=56$ ). For revegetation, I used the most recent vegetation baseline inventory with 22 revegetation types, each based on many transects. A lesser amount of summed ground cover in the final column of Table 5 indicates more basal area of plants in revegetation. 
Table 5. Percent bare ground, rock, and litter pre-mine and in revegetation.

\begin{tabular}{lcccc}
\hline CATEGORY & BARE GROUND & ROCK FRAGMENTS & PLANT LITTER & TOTAL \\
\hline PRE-MINE & 22 & 15 & 58 & 95 \\
REVEGETATION & 13 & 2 & 72 & 87 \\
\hline
\end{tabular}

Western wheatgrass is arguably the most successful revegetation grass in the long run, and the only native that can suppress and replace cheatgrass reliably if slowly. It is not, however, one of the strongest establishing. Rosana western wheatgrass originated in nearby Rosebud County (the Ros in Rosana), and aside from being well-adapted, it spreads vigorously from rhizomes.

Overall, the trend for western wheatgrass has been a doubling of relative cover in the midterm and a tripling over one decade or a bit longer (Table 6). If stress kills some plants one year, western wheatgrass can quickly fill vacant habitat vegetatively when favorable conditions return.

The fact that Rosana western wheatgrass has replaced cheatgrass in many fields at DCM, nearly in the absence of any other species (Prodgers, 2013), does not necessarily predict its behavior in successful seedings because its performance depends not on the species with which it must compete as much as site factors.

Table 6. Temporal trends in relative perennial canopy coverage of western wheatgrass, sheep fescue, and cheatgrass, where important, SCCM.

\begin{tabular}{lccc}
\hline & \multicolumn{2}{l}{ FIELD AGE YEARS } \\
& INITIAL & $3-7$ & FINAL \\
& & & \\
\hline & RELATIVE CANOPY COVERAGE \% & 24 \\
Western Wheatgrass & 7 & 14 & \\
Sheep Fescue & & & 47 \\
$\quad$ Where Seeded & 12 & 27 & 19 \\
$\quad$ Where Unseeded & 1 & 11 & 15 \\
Cheatgrass & 15 & 24 & \\
\hline
\end{tabular}

DCM had fewer successful seedings than SCCM, particularly 1999-2001. This gave western wheatgrass free rein to spread vegetatively, and since it spreads even amongst annual-biennial weeds that persist in poor seedings, it came to be prevalent at DCM. In the 2007 monitoring at DCM, $80 \%$ of perennial grass cover came from a single species, western wheatgrass. 
Sheep fescue has an entirely different strategy: filling suitable habitat by producing copious seed capable of establishing on the ground surface. Phil Grime (1979) used sheep fescue as an example of a stress-tolerant competitor - a formidable combination of traits.

Where seeded, sheep fescue increased more over time than western wheatgrass. Where unseeded but proximate to a field where it was seeded, it invaded and increased most impressively (Table 6). This bespeaks an invasive species, but it has not moved into nearby rangeland - yet. The members of the Festuca ovina complex available as commercial seed are introduced, but when seeded in the 1990s, Covar was listed in seed catalogs as native.

Cheatgrass, the bequest of direct-haul top soiling and the weed that replaces annual forbs in poor seedings, exhibited essentially no net trend (Table 6). Where accompanied by western wheatgrass, cheatgrass reduces, sometimes quite dramatically. Where situated among bunchgrasses and shrubs or few perennials of any type, cheatgrass can hold its own, apparently indefinitely, within the context of the annual dynamic. Once cheatgrass establishes a seedbank, two years at most, any tillage or drill seeding promotes cheatgrass germination. That is why vegetative spread is most effective in supplanting cheatgrass.

\section{$\underline{\text { Peak Standing Crop }}$}

Productivity of revegetation exceeds the pre-mine condition by a wide margin. Revegetation is better stocked with more productive plants than the pre-mine vegetation or standards derived from them (Tables 2 and 3). Table 7 shows the temporal trend in annual productivity measured as PSC and also places it in the context of the grazing-land performance standard and pre-mine grassland. (Steppe is a minor pre-mine type, but has the highest PSC apart from pastureland, Table 2.)

The productivity explosion that attends revegetation is apparent by casual inspection. The first-year crop of kochia in a good year can produce 6-9 tonnes/ha (3-4 tons/acre) of phytomass. The subsequent increase in perennial PSC as annuals subside (kochia auto-suppresses) and perennials achieve mature stature is unsurprising. The continuation of this trend after one decade is, at least to me, unexpected. At some point, productivity probably will equilibrate nearer the premine level.

Pre-mine vegetation has been selected by heavy livestock grazing from the late $19^{\text {th }}$ century into about the latter third of the $20^{\text {th }}$ century, when grazing as indicated by historic livestock 
numbers in Big Horn County tapered off. Rangeland production is dominated by cool-season grasses, many senescent. Sagebrush provides a lot of cover but is rather unproductive, especially mature and senescent plants. The final increment of annual growth comes from a variety of forbs and several subshrubs that owe their occurrence to their habit of growing close to the ground, largely escaping cattle grazing. Examples are Hood phlox and littleleaf pussytoes. Others are unpalatable, a few poisonous. More bare ground is exposed in rangeland than in revegetation (Table 5).

Table 7. Temporal trends in perennial PSC (a measure of productivity), pre-mine PSC (shrub-steppe), and the performance standard for grazing land, SCCM.

\begin{tabular}{lccc}
\hline \multicolumn{4}{c}{ FIELD AGE YEARS } \\
CATEGORY & $1-2$ & $3-7$ & $10+$ \\
& & & \\
\hline & $-\ldots--$ & - & $-K G / H A$ \\
PRE-MINE & 625 & & \\
STANDARD & 775 & & \\
REVEGETATION & 1100 & 1500 & 1700 \\
\hline
\end{tabular}

Most of the PSC in coal mine revegetation comes from a few well-adapted, eurytopic cultivars that were selected for vigor (keys for productivity) and seed production, among other desirable traits. The prevalence of these cool-season grasses probably accounts for most of enhanced productivity in conjunction with denser stocking.

The stimulating effect of tillage on the microflora and mineralization of nutrients may also promote elevated productivity in revegetation. Whether this could explain an increasing trend for more than one decade is debatable.

Shrub Density

In Decker coal revegetation, the main shrubs are big sagebrush, fourwing saltbush, greasewood, and winterfat. (Native winterfat is better classed a subshrub, but the variety used in revegetation can grow one meter tall with woody stems $2 \mathrm{~cm}$ thick.) While SCCM has some fine sagebrush revegetation, heavy-seeded shrubs such as greasewood and fourwing saltbush are more easily established from drill seeding. 
Shrub density declined with time; this occurred in $81 \%$ of shrub-steppe fields. Table 8 lists results for five fields where shrubs increased ("increaser" fields) and 22 where they decreased. Only fields that began with $>500$ shrubs/ha were included in analysis, although mean density was $8,000 /$ ha in the first two years. Because the shrub quantity varied so greatly among fields, relatively few fields had very high shrub densities (up to 24,500 shrubs/ha) which skewed the mean density. Instead of shrub density per se, I used the percentage change from the first measured density to summarize trends in Table 8.

Both those fields that increased and decreased in the long term tended to increase initially. The explanation is that shrubs in the first or second year can go undetected, depending largely on the profusion of annuals. As they grow larger, they are more reliably detected. Field observations also suggest delayed seed germination in a few cases, especially on suitable spoil, where herbaceous competition is less.

Table 8. Shrub survival as a function of field age, SCCM revegetation.

\begin{tabular}{lllcr}
\hline DENSITY & INITIAL SHRUB & \multicolumn{3}{c}{ FIELD AGE YEARS } \\
TREND & $\begin{array}{l}\text { DENSITY } \\
\text { (INDIV/HA) }\end{array}$ & $1-2$ & $3-7$ & FINAL \\
\hline & & & & \\
DECREASER & 8,650 & 100 & 111 & 68 \\
INCREASER & 5,110 & 100 & 139 & 146 \\
ALL FIELDS & 8,000 & 100 & 116 & 82 \\
\hline
\end{tabular}

A few fields, however, experienced real increases from shrub regeneration after the initial plants produced seed. This is largely limited to special substrates, e.g., suitable spoil, that do not support much grass growth and provide bare soil for arriving shrub seed to colonize.

All of the major shrub species declined over time. The reason for most shrub mortality is conjectural, but climatic unsuitability arising from distant genotype origin is strongly suspected. The timing of important events like flowering, seed set, germination, and dormancy may conflict with the mine's climate. Fourwing saltbush, arguably the easiest shrub to establish, recently experienced significant die-off of mature plants, as did winterfat and other shrubs (including sagebrush) to lesser extent.

Browsing was not a significant cause of shrub mortality except for rubber rabbitbrush, the shrub most heavily cropped. Uncommon occurrences also can take a toll, as when a severe summer 
hailstorm killed sagebrush and other shrubs in the eastern SCCM fields and nearby rangeland but skunkbush sumac survived the pummeling.

The Sodic Overburden Test Plots (SOBTP), seeded in fall 1995 and spring 1996 and were monitored for 10 years, provide another analysis of shrub trends (Table 9). This experiment had two big blocks, $1.2 \mathrm{~m}$ (4') and $2.4 \mathrm{~m}$ (8') of suitable material over sodic spoil, and within them three substrates (topsoil, spoil, and scoria) and three seedings. Each treatment was replicated thrice. The same transects marked with rebar were sampled each time, allowing accurate shrub counts.

The temporal trend shows the biggest declines in the early years and apparent equilibration at the end of monitoring (Table 9). Shrub density declined twice as much in one block as in the other. Despite the large difference in initial density on the two blocks, densities ended up about the same. It is interesting to speculate that the greater the initial shrub density, the greater the decline.

Another trend observed at the SOBTP is that spoil provided three to four times more shrubs than "topsoil" seeded with the same mix, whereas scoria, seeded with the same shrubs and in addition two sagebrushes, was in between. Additionally, many shrubs growing in topsoil were frail and easily damaged when sampling; livestock presence would exact much shrub mortality.

Table 9. Shrub survival as a function of field age, Sodic Overburden Test Plots.

\begin{tabular}{|c|c|c|}
\hline AGE (YRS.) & 1.2 M (4’) Suitable Fill & 2.4 M ( (8’) Suitable Fill \\
\hline & \multicolumn{2}{|c|}{ - - - - - - - -INDIV/HA (\% SURVIVAL) - - - - - - - - - } \\
\hline 4 & $8,370 \quad(100)$ & 17,700 \\
\hline 7 & $7,490 \quad(89)$ & 10,350 \\
\hline 10 & 2,580 & 2,670 \\
\hline 11 & 2,460 & 2,520 \\
\hline
\end{tabular}




\section{Practical Lessons}

For practitioners, SCCM provides a bonanza of revegetation lessons because of its innovative seedings, several distinctly different substrates, and multitude of interseedings. This knowledge was hard-earned, and some of the lessons are just now being implemented.

Bond-release revegetation objectives, to refresh, are first to establish a lot of sagebrush; lacking that, to establish enough total shrubs to meet the wildlife shrub standard in Table 3; and lacking that, to establish enough shrubs in conjunction with plant cover and PSC for grazing land. Every field is hoped to be wildlife habitat because that is the largest land-use commitment. Given the temporal loss of shrubs just documented, more shrubs are better.

The second main revegetation challenge is dealing with annual weeds, the consequences of which have become increasingly dire. Simply interseeding weed patches rarely works. These are the lessons most likely to benefit other coal mines in the larger Powder River Basin.

\section{Promoting Shrub Establishment}

Role of Substrate in Shrub Establishment. Substrate can influence shrub establishment and survival more than seeding practices. Three basic revegetation substrates are: 1) topsoil (the salvaged upper $15 \mathrm{~cm}$ [six inches]); 2) suitable spoil (salvage more than $15 \mathrm{~cm}$ deep, meeting chemical and physical criteria typical for Montana and Wyoming); and 3) scoria. (Scoria is what locals call reddish sedimentary deposits that have been metamorphosed by burning coal veins and resembling geologic scoria. It is more properly termed clinker, a term rarely heard locally.)

The right spoil is fine shrub habitat but poor weed and grass habitat. When SCCM got its first spectacular sagebrush field (Fig. 1), for which it received an OSM Excellence in Mining Award, everyone involved tried to recall what they did differently there - to no avail. When sampling there later, I observed that the substrate appeared more like spoil than the usual topsoil salvage, as denoted by color and soft rock chunks of the type seen on pit walls. Suitable spoil also was the best shrub substrate in some SOBTP plots constructed and seeded in spring 1996.

Another example demonstrating the superiority of suitable spoil for Chenopod shrubs (i.e., fourwing saltbush, winterfat, and greasewood) comes from PAR 7E at SCCM seeded in March 2013. The same upland-shrub-steppe-seed mix was applied everywhere except drainages. Some topsoiled portions became weedy if productive (Fig. 2), while others were more satisfactory 
(Fig. 3). Those areas not receiving coversoil, however, had spoil at the surface. The unmapped spoil was seeded identically. This portion of 7E has lots of shrubs, few weeds, and noticeable bare dirt (Fig. 4). As plant habitat, some spoil is superior for shrubs and grasses yet still excludes weeds (Fig. 5).

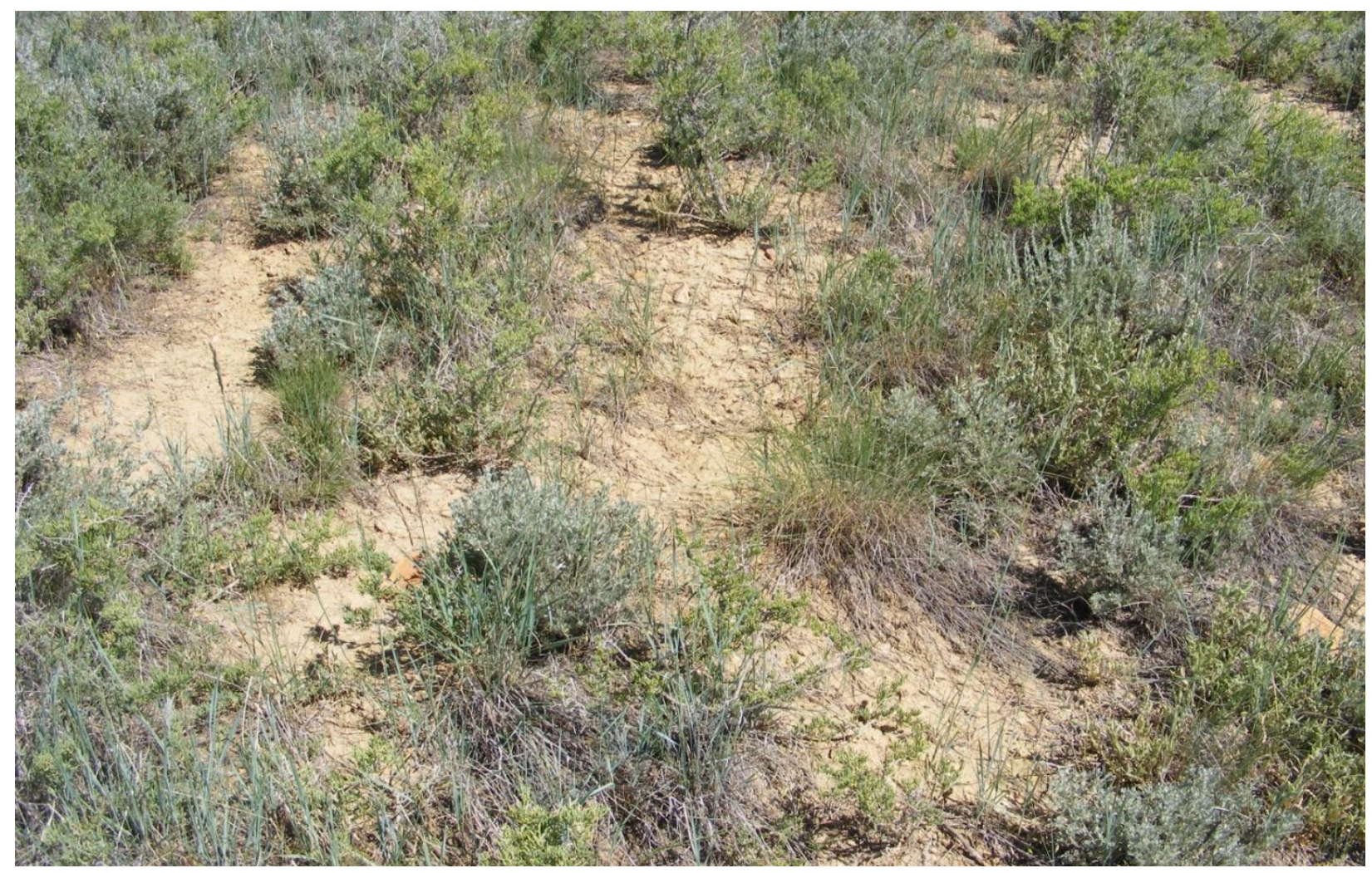

Figure 1. Sagebrush and greasewood growing on spoil in SCCM's PAR 2C, seeded 1999 and photographed 2009. Note exposed soil and lack of weeds. 


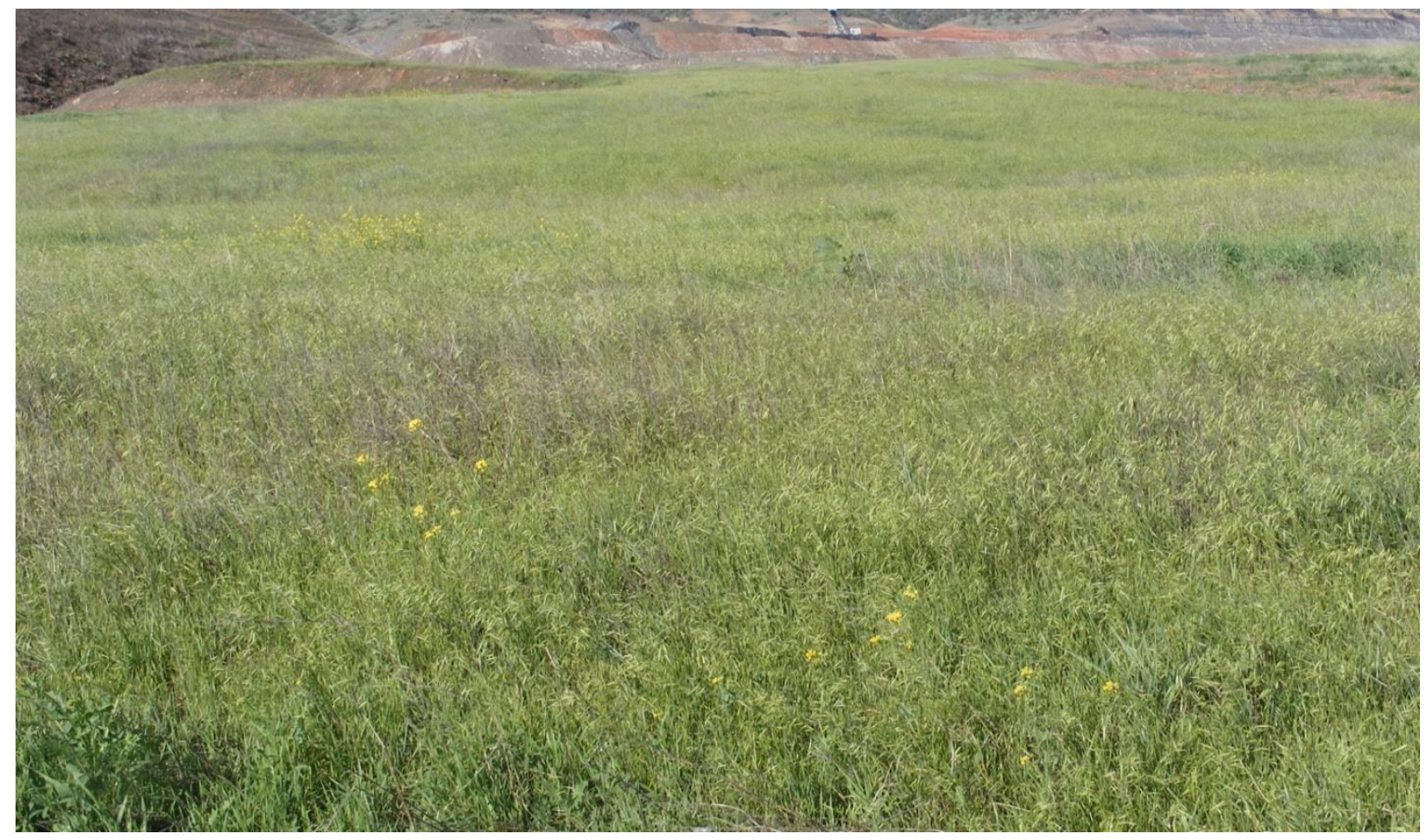

Figure 2. Two-year-old topsoil revegetation in eastern PAR 7E (SCCM) is weedy with cheatgrass following kochia and mustards. The cheatgrass came from salvaged topsoil.

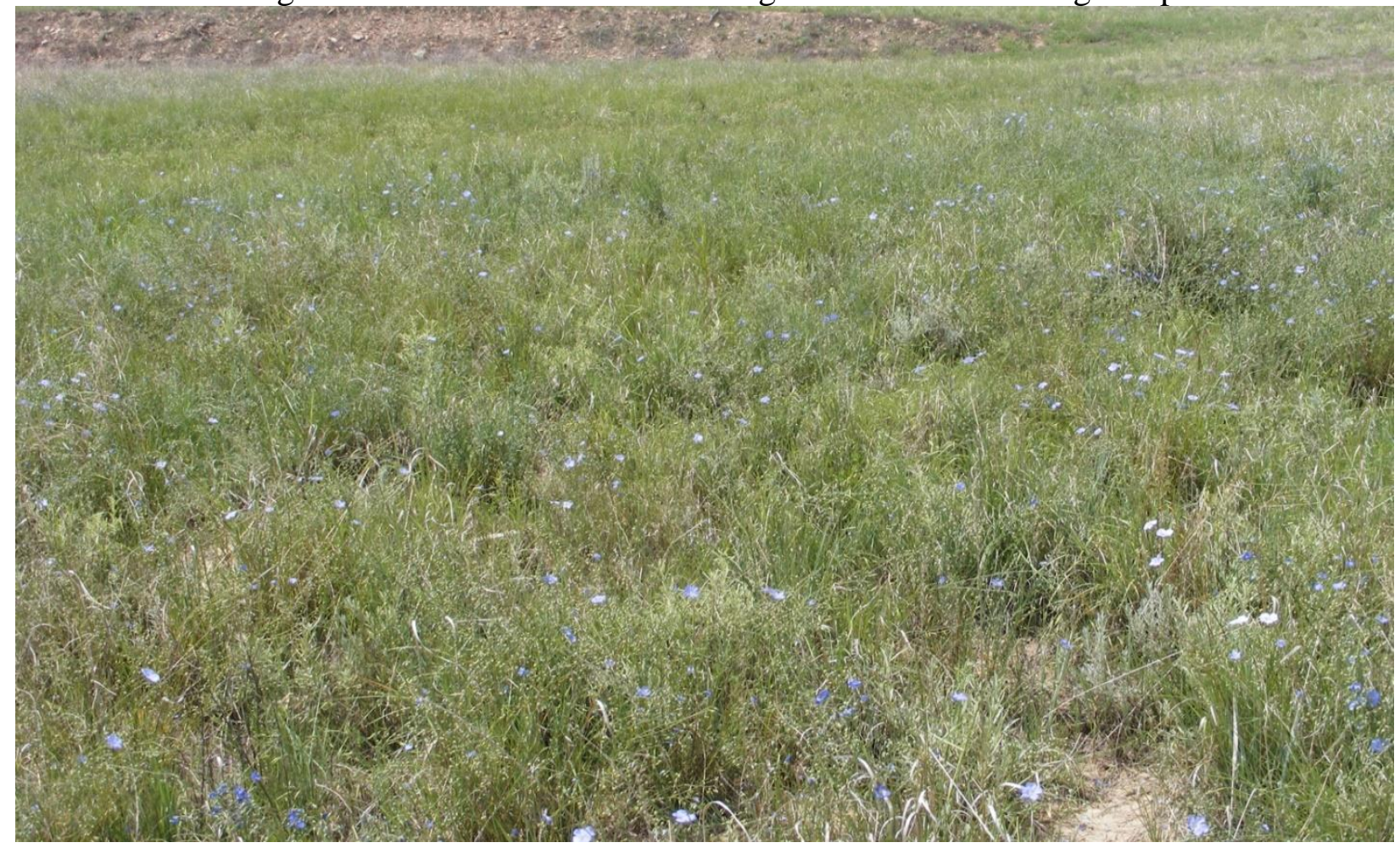

Figure 3. One of the better parts of PAR 7E where an upland shrub-steppe mix was seeded on topsoil. It is productive and has a useful amount of Chenopod shrubs. 


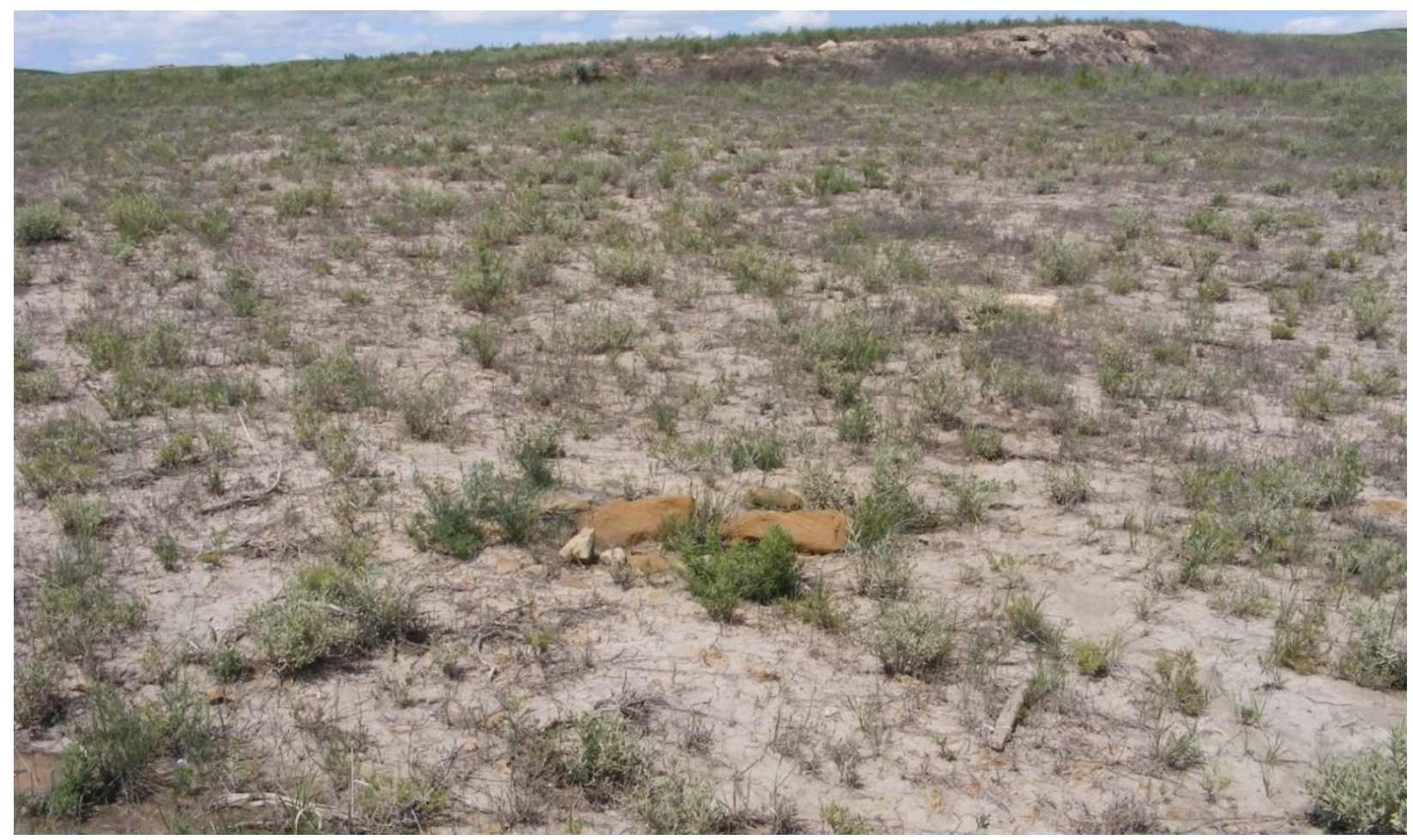

Figure 4. The spoil substrate in 7E, seeded as in Figs. 2 and 3. It is stressful habitat with a lot of bare soil; the Chenopod shrubs are growing slowly as are the grasses and alfalfa.

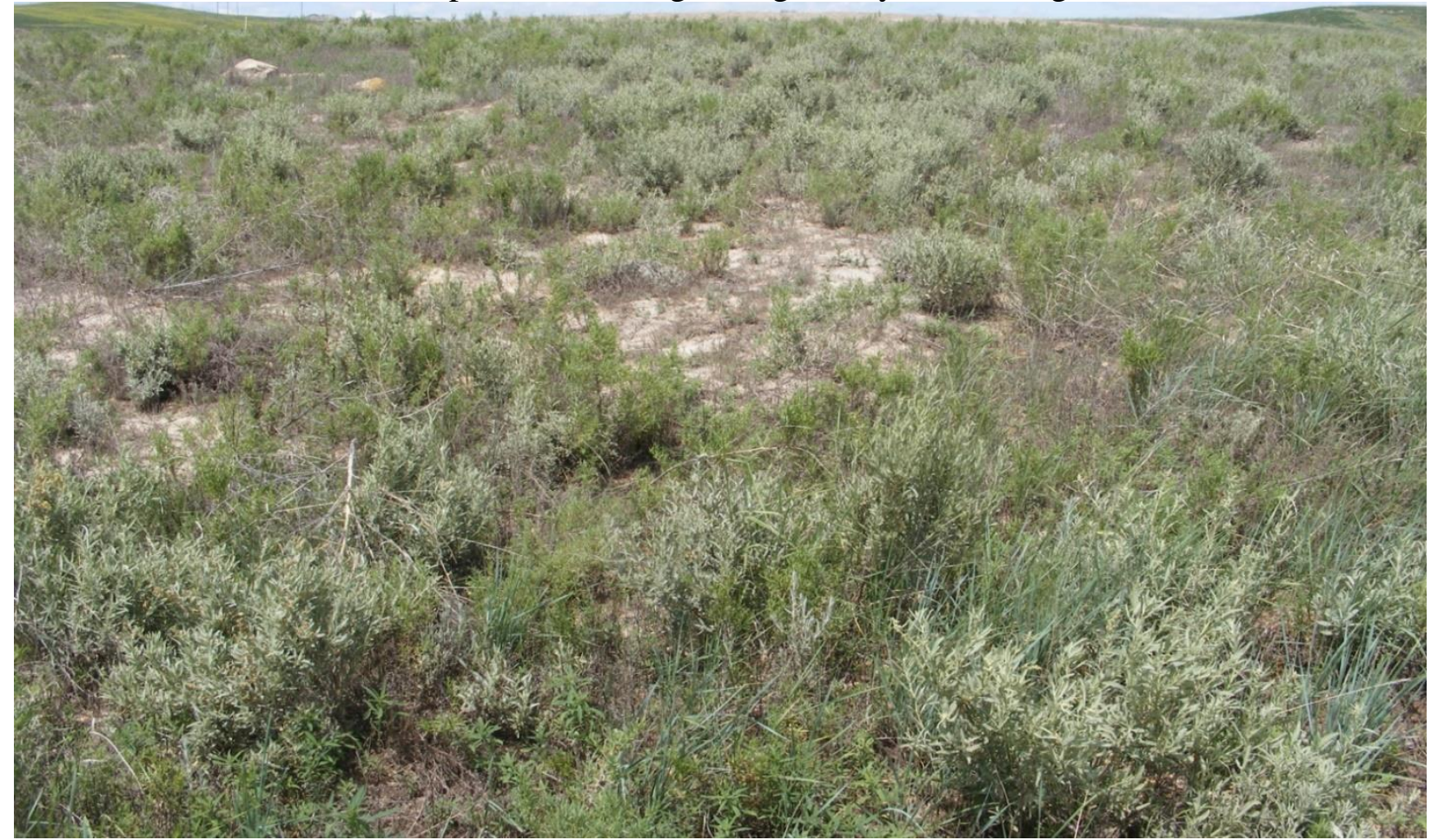

Figure 5. Still PAR 7E seeded as in Figs. 2-4, the Chenopod shrubs in this particular spoil are 2$3 \mathrm{X}$ larger than in the previous figure. In addition, more grass and scattered small sagebrush are present. As plant habitat, spoil quality varies from very poor to excellent. 
Spoil that supports good revegetation can simultaneously reject weeds, making it doubly desirable. Figure 6 shows two adjacent seedings where the same mix was applied. On left, topsoil is weedy, and the shrubs are small and weak. On right, weeds are all but absent and shrubs are vigorous as well as more numerous, but productivity is less. In Fig. 7, weed-free spoil revegetation is contrasted with conventional topsoil revegetation in the field to the north.

Some "suitable" spoil, alas, is poor habitat for most plants (Fig. 8). MDEQ's Unsuitability Criteria for Overburden and Regraded Spoils have "suspect levels" for $\mathrm{pH}$, salinity, textural class, sodium adsorption ratio (SAR), and other parameters. Spoil used for revegetation meets these criteria given the uncertainties of sampling. Nonetheless, some spoil has provided complete revegetation failures, requiring that topsoil be applied over the spoil. It remains for the mines to better quantify the attributes that distinguish good spoil from bad, and to collect samples enough to assure that spoil with good attributes plays a larger role in revegetation.

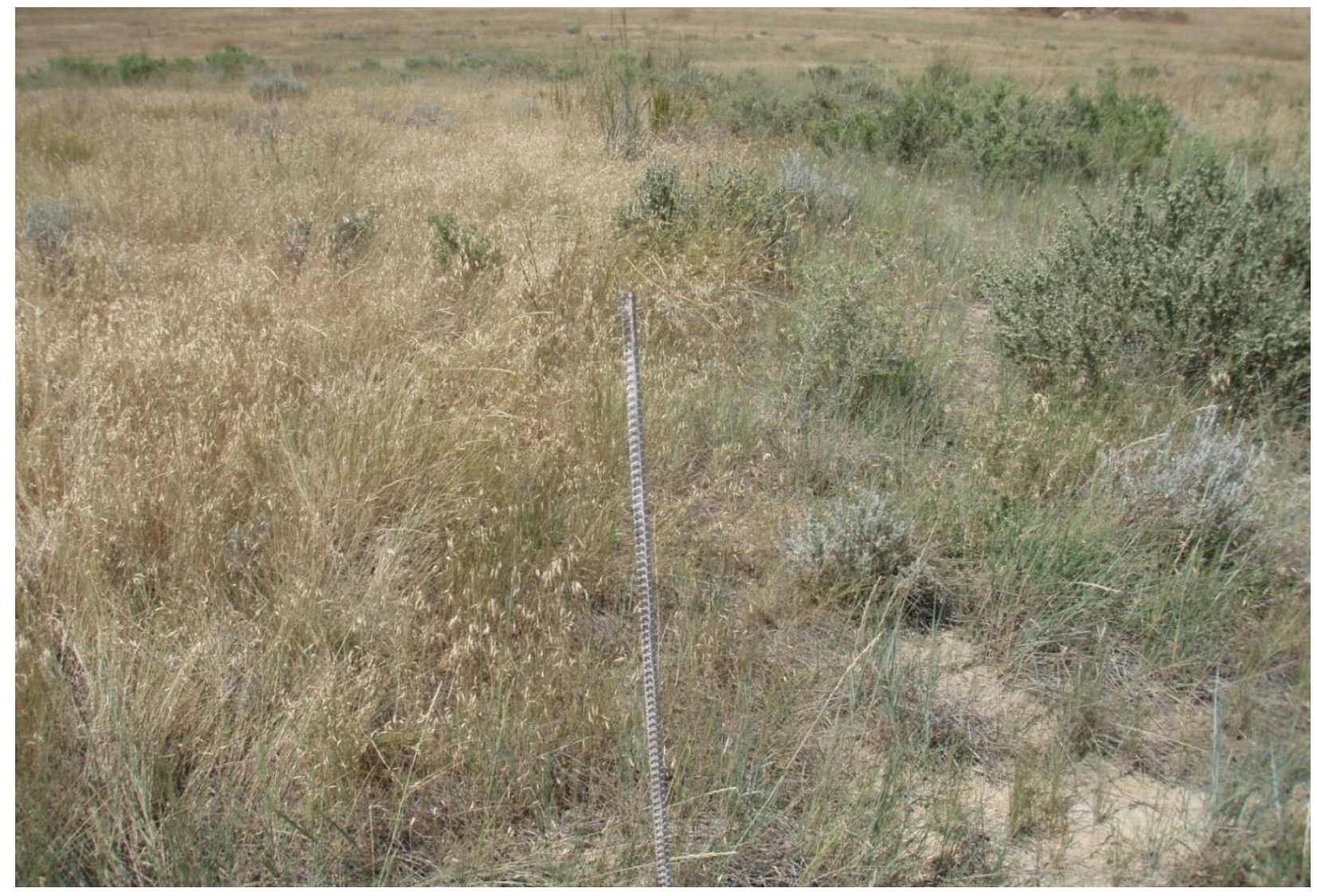

Figure 6. Topsoil (left) and spoil (right) seeded with the same mix. Spoil has fewer weeds despite having more exposed dirt, and more and bigger shrubs 10 years after seeding. 
JASMR, 2016 Volume 5 Issue 1

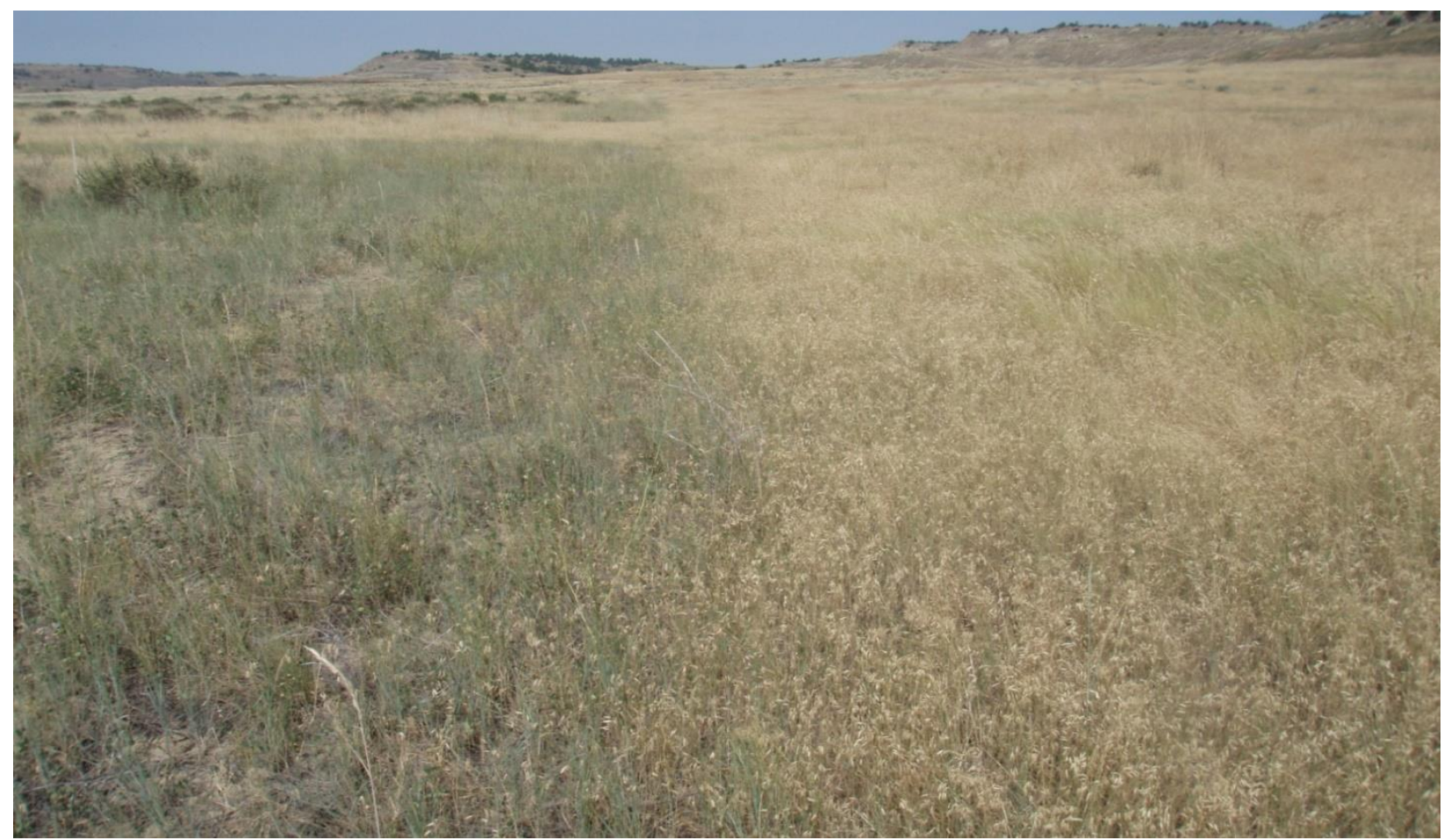

Figure 7. While differently seeded in 1995-1996 and photographed in 2009, spoil on left is clearly poor cheatgrass habitat while topsoil on right (seeded one year earlier) maintained cheatgrass for one decade.

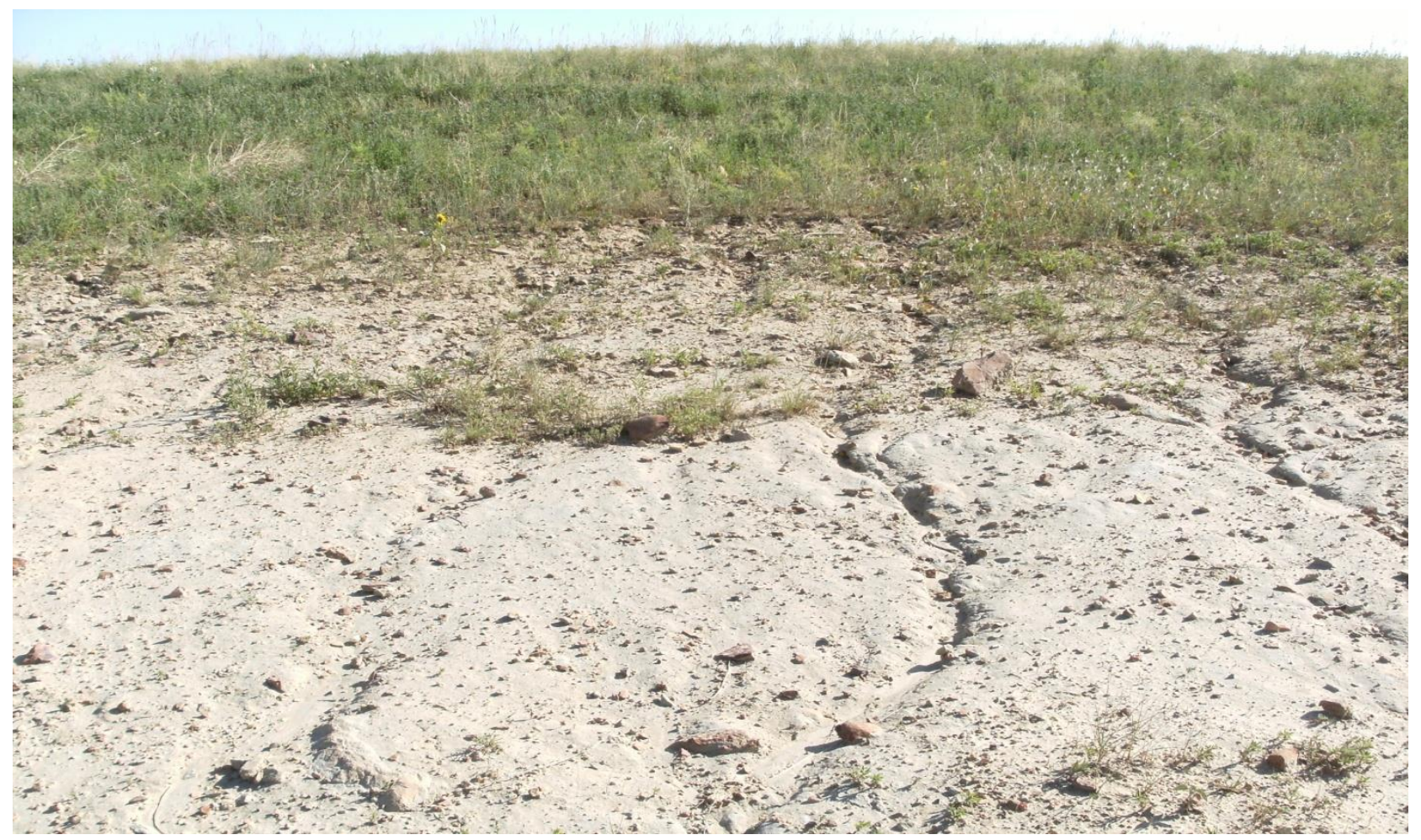

Figure 8. This spoil is poor plant habitat; seeded coversoil with some shrubs above spoil. 
Most revegetation at both mines is on direct-haul or stockpiled topsoil. Topsoil is productive but weedy because the seedbank usually manifests far more cheatgrass and sometimes sweet clover than native perennials, which are rarely seen. Topsoil is also great kochia habitat; a sward of meter-tall kochia can overtop desired perennials the first year.

Scoria, the other special substrate, has provided some fine shrub revegetation and an equal number of disappointments. DCM has achieved both rabbitbrush (Fig. 9) and sagebrush (Fig. 10) on scoria.

After early success at the SOBTP, SCCM has had a number of disappointing scoria seedings, including some turning into alfalfa pastures (Fig. 11). Scoria has an affinity for legumes including sweet clover, so one pound of yellow-flowered alfalfa (the drought-tolerant variety) was seeded along with 13 pounds pure live seed of cool- and warm-season grasses, forbs, a proven native legume (white prairie clover), four forbs, and three shrubs. Alfalfa was removed from the scoria mix.

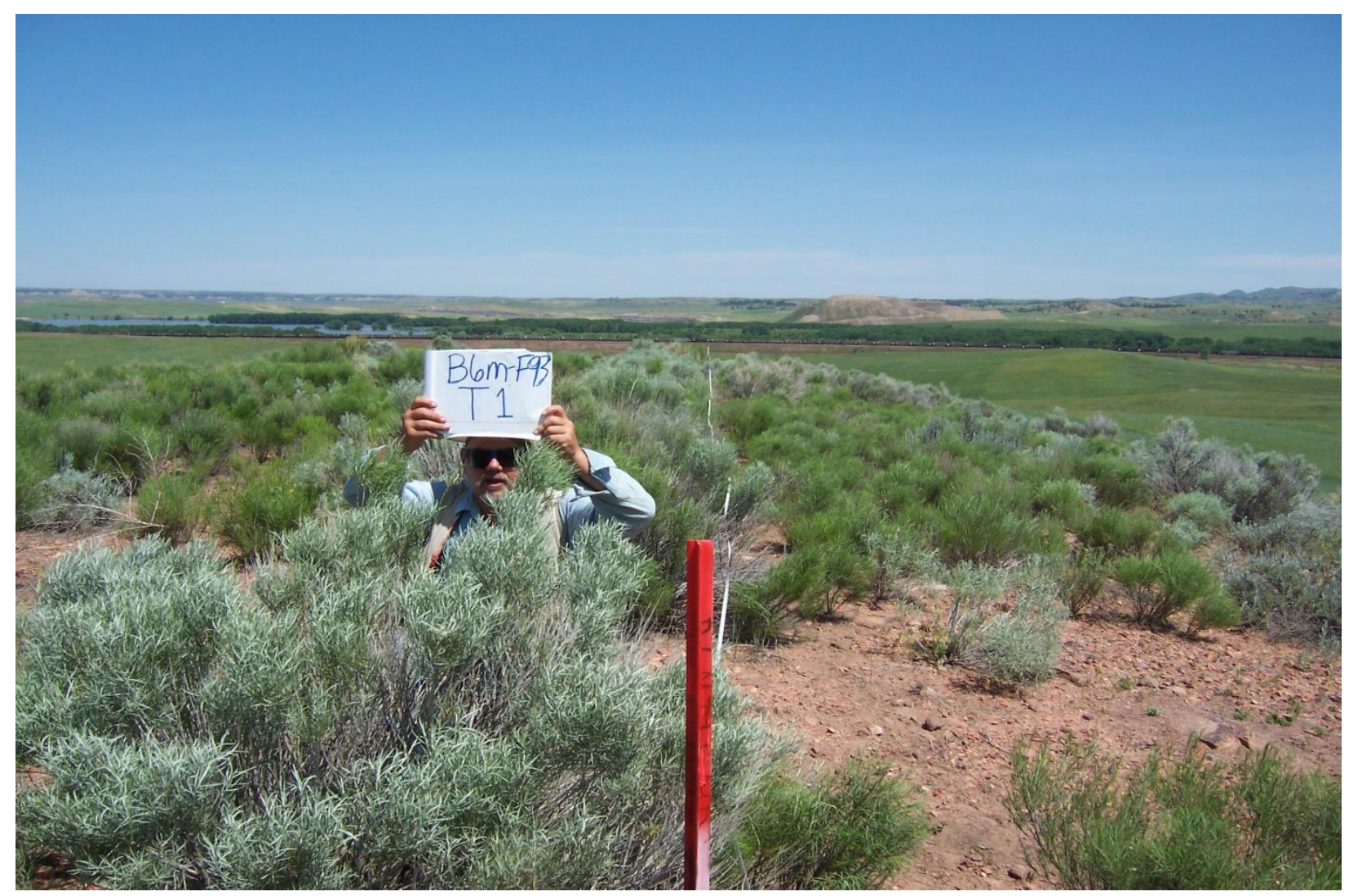

Figure 9. Mostly rabbitbrush revegetation on scoria at DCM. 
JASMR, 2016 Volume 5 Issue 1

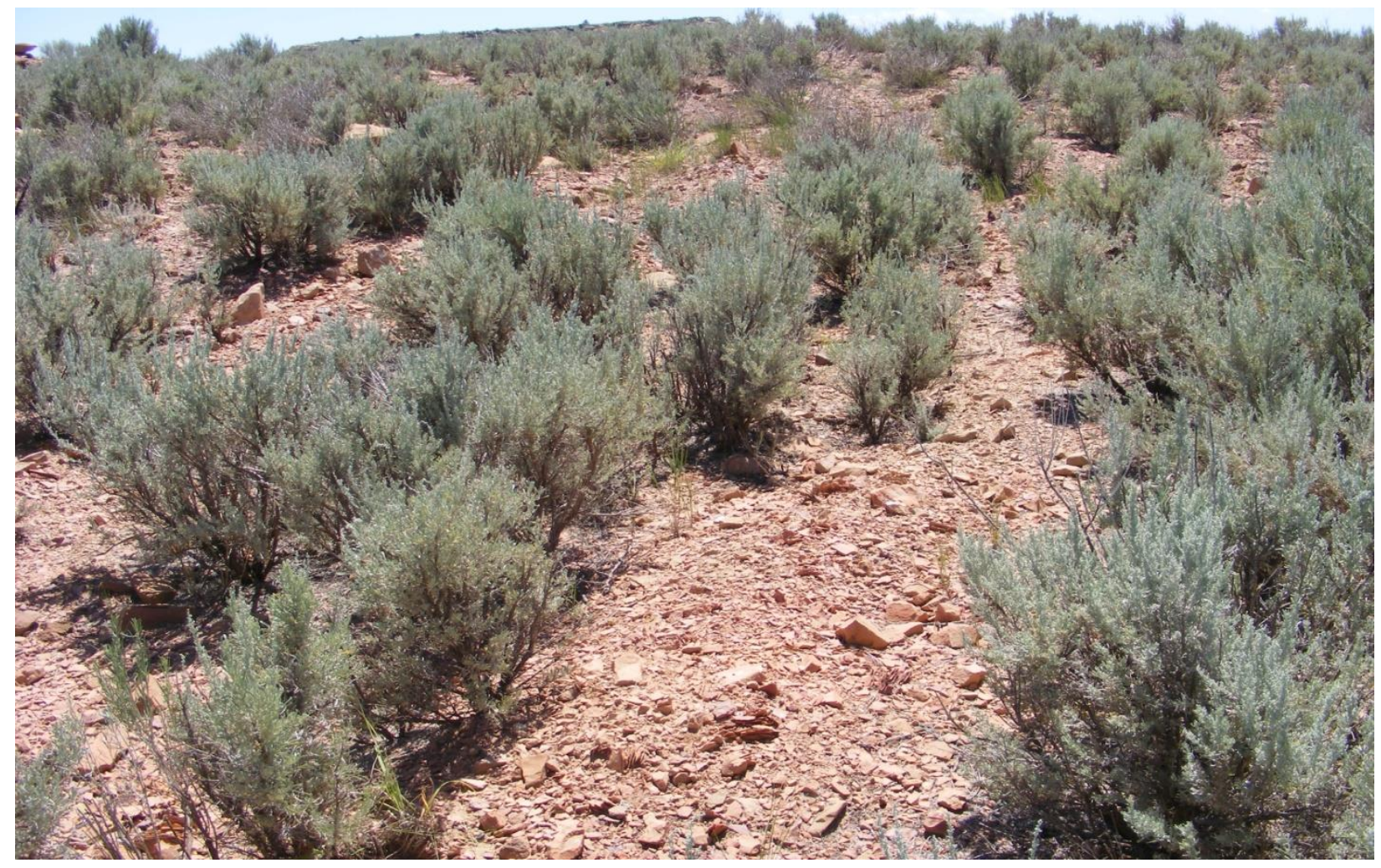

Figure 10. Big sagebrush growing on ripped scoria substrate, DCM. Note coarse rock.

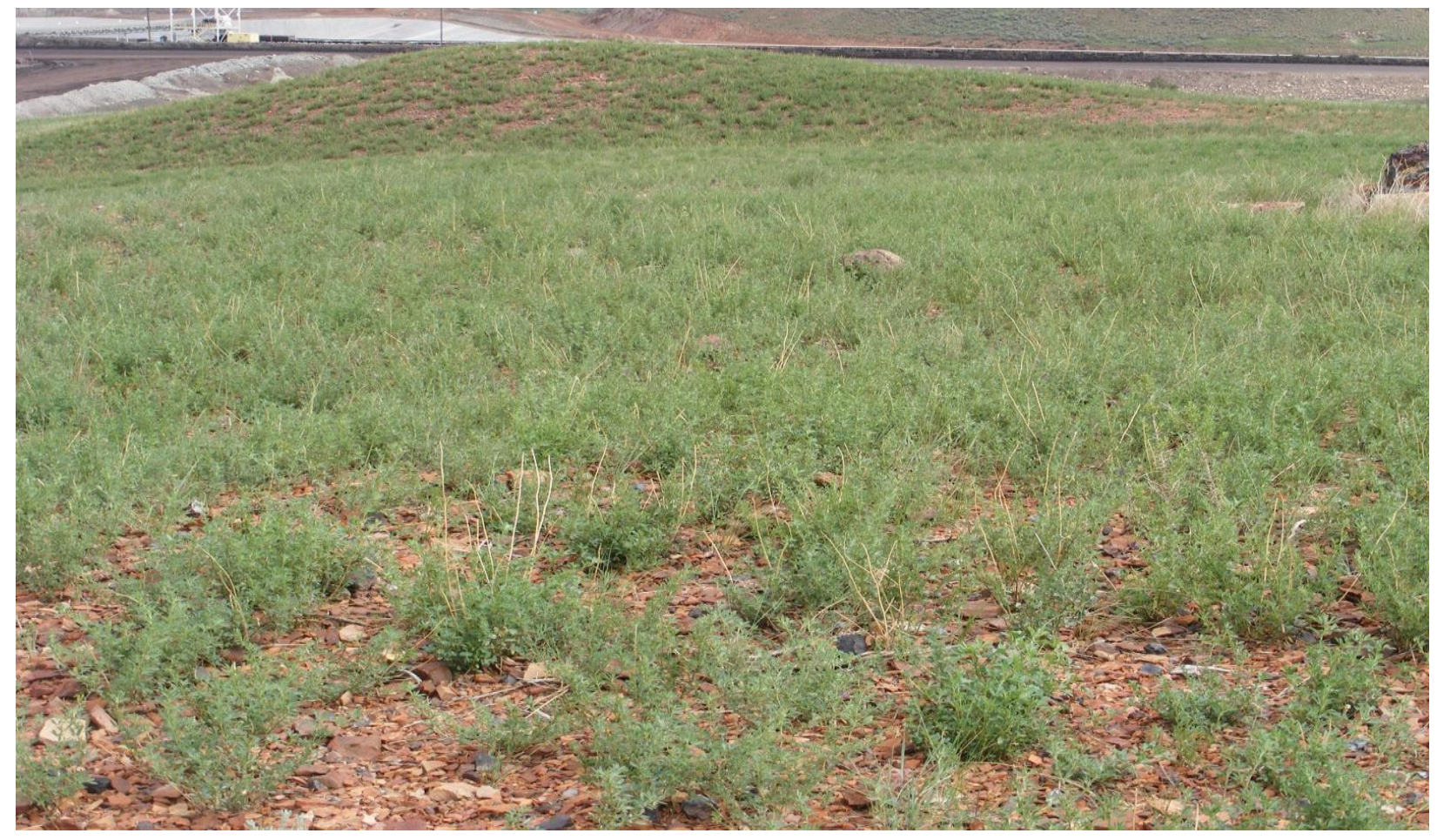

Figure 11. Diverse scoria seeding that turned up mostly yellow-flowered alfalfa (SCCM). 
At SCCM's SOBTPs, scoria was the premier diversity substrate, turning up a number of unseeded species (Fig. 12.) One of the legumes, prairie milkvetch, became important on spoil and scoria, and white locoweed only on scoria.
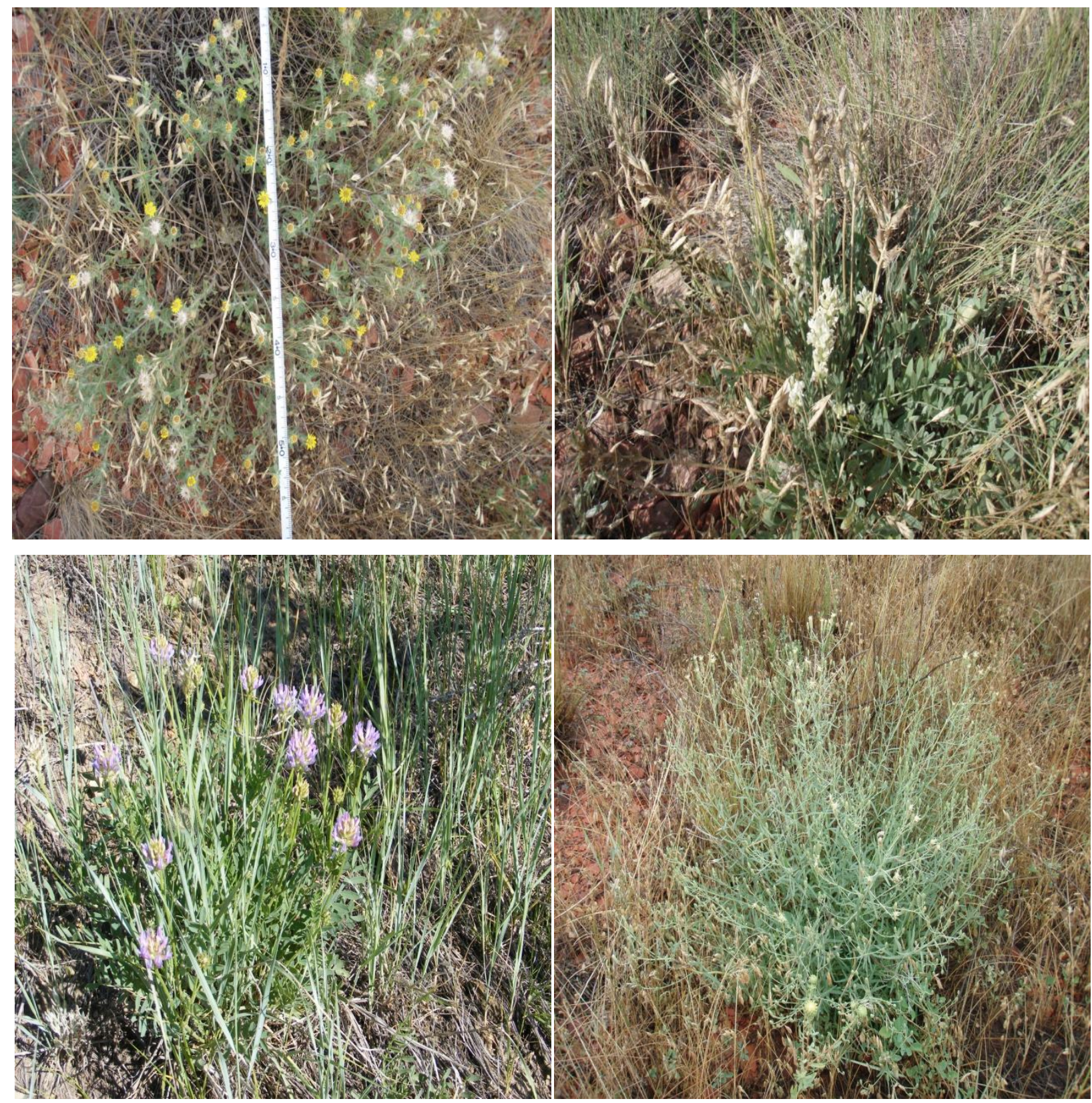

Figure 12. Clockwise from upper left: hairy false goldenaster, white locoweed, false boneset, and prairie milkvetch on scoria at SCCM's sodic-overburden test plots, seeded spring 1996 and photographed 2007. Such profusion of volunteer native perennials is unusual in revegetation at the Decker mines. 
It is perhaps worth relating here that alfalfa accidentally seeded in the early 1990s soon perished. It was too dry then (Table 1). Now, the combination of more mesic precipitation regime and more drought-tolerant alfalfa allow the introduced legume to persist.

\section{Role of Seeding in Shrub Establishment}

While seeding practices vary temporally through adaptation, the mines typically purchase seed for each mix in two sets of bags, one containing heavy seed ( $<300,000$ seeds/pound) and the other containing light seed. On topsoil the heavy seed is drilled while the light is broadcast, usually in a single operation. This places the seed in or on the ground optimally according to seed characteristics. Scoria is usually broadcast-seeded followed by an aggressive rake harrow; much of the seed falls into voids among scoria rock fragments.

Chenopod shrubs (greasewood, fourwing saltbush, and winterfat, all heavy seed) can be established with fairly regular success on all three substrates by drill seeding them along with other strong-establishing herbs. This is the most assured way to get enough shrubs for wildlife habitat on topsoil (Fig. 13). The mines seed about one pound PLS/acre of each Chenopod shrub within a total seed rate of around 13 pounds PLS/acre, mostly cool-season grasses.

On the heavy soils near Decker, big sagebrush is much more difficult to establish in quantity, although SCCM has had many successes (e.g., Fig. 14). Just adding sagebrush to the normal seeding accomplishes little on topsoil. Nine pounds of sagebrush seed was applied to part of a SCCM field (PAR 4J seeded 11/08) as an afterthought. Only a few individuals could be found among the dense grasses (Fig. 15).

Often sagebrush seedlings are revealed in narrow openings among the grasses, for example where created by plugged seed drills (Fig. 16). This observation provided the model for spatially segregating heavy seed (e.g., wheatgrasses, Chenopod shrubs) from light seed including sagebrush seeded at 2-3 pounds PLS/acre. The field still needs cover and production (Table 3) in case the wildlife shrub standard goes unmet.

For sagebrush, any seeding technique that spatially separates the light shrub seed is worth trying (Fig. 17). A field-level approach is to seed the entire field with light seed, for example with a Grasslander ${ }^{\mathrm{TM}}$ seeder (a controlled broadcast seeder followed by a continuous bank of packer wheels, Fig. 18), then drill seed a portion of the field separately with a drill seeder and a mix containing Chenopod shrubs. 


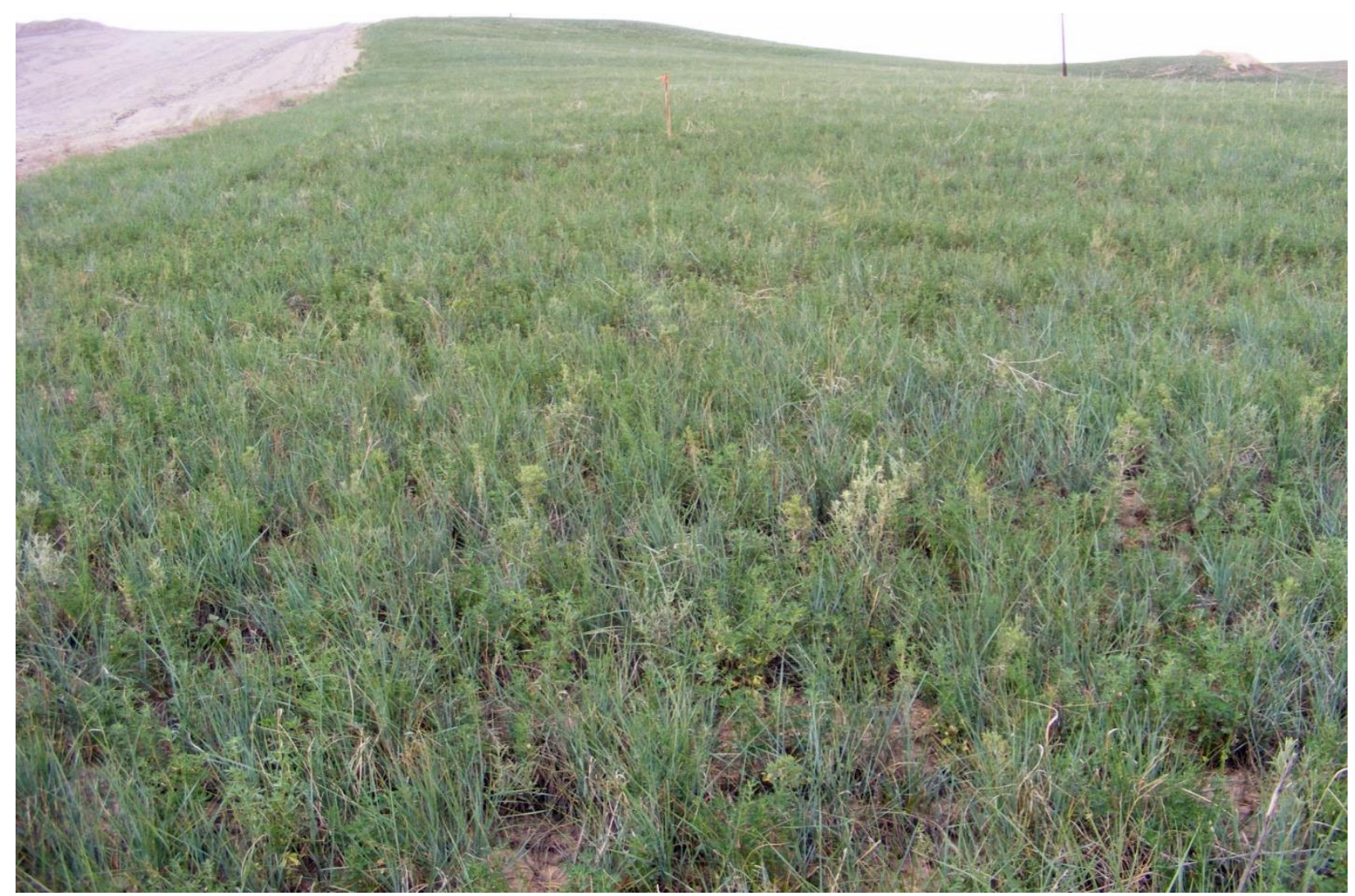

Figure 13. Good Chenopod shrub establishment with plenty of grass on topsoil from drill seeding, SCCM. This is a competitive scenario, and shrubs grow rather slowly.

For a more uniform seeding, a seeder with two seed boxes, one for grain and one for legumes, can be modified to drill seed the heavy-seeded grasses and Chenopod shrubs at wide spacing by plugging some drill tubes but broadcasting light seed everywhere from the legume box with a good agitator or seed-feeding mechanism. The light seed is dropped from every tube or hose (Fig. 19) close to the ground to prevent light seed from blowing away.

\section{Contending with Annual Weeds}

Seeding would be easier and revegetation practices more effective were it not for the annual weeds that can impair or doom promising seedings through interference competition. The ensuing litter of annuals prevents inter-seeding from achieving proper soil-seed contact. Should perennial seed germinate, the new crop of annuals overwhelm slower-growing plants. Where annuals persist, all manner of inter-seedings have failed. 
JASMR, 2016 Volume 5 Issue 1

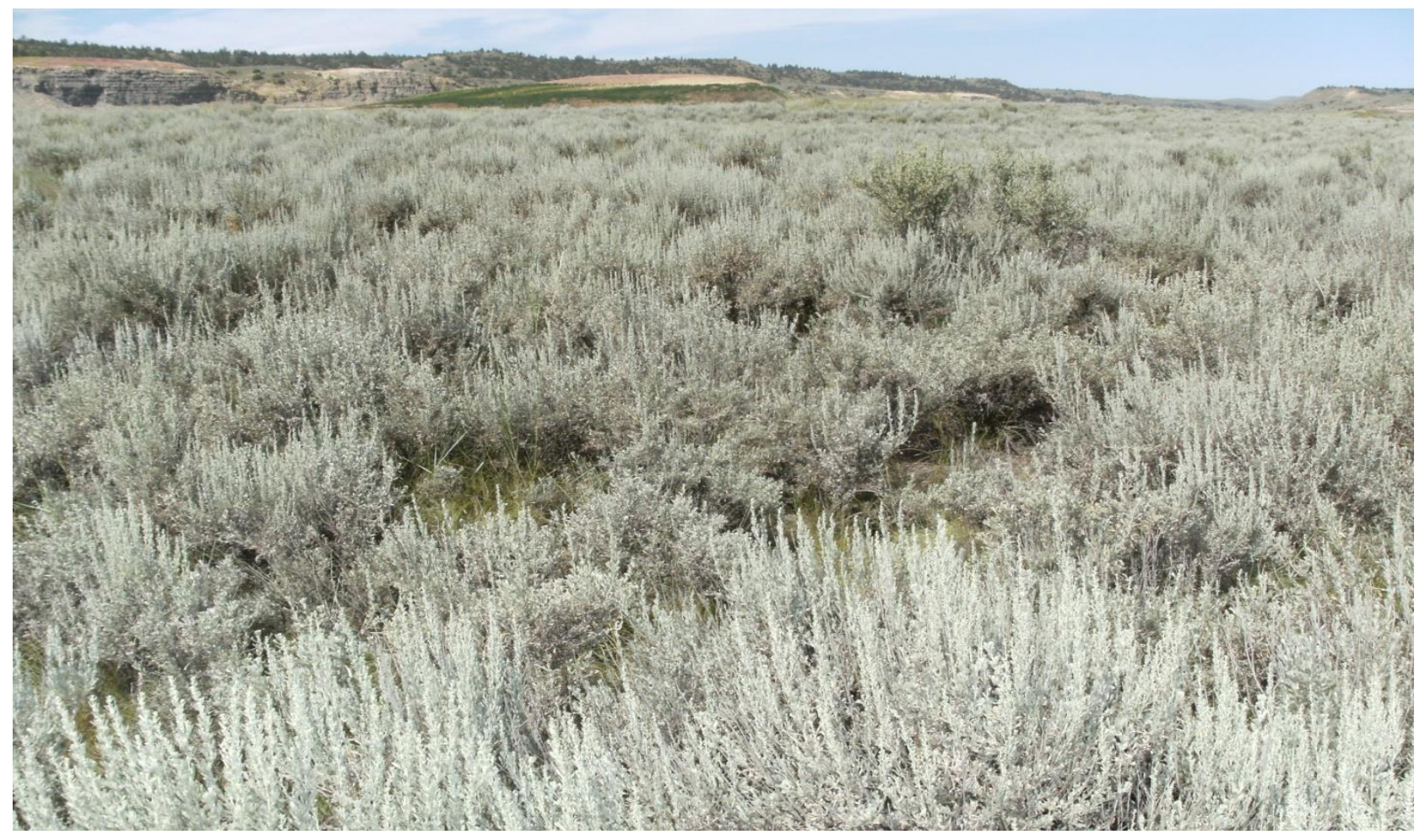

Figure 14. SCCM has many good sagebrush seedings, but it cannot replicate them consistently. The best strategy is to seed portions of fields with sagebrush and portions with grasses and Chenopod shrubs. This can be applied at a scale of feet or acres.

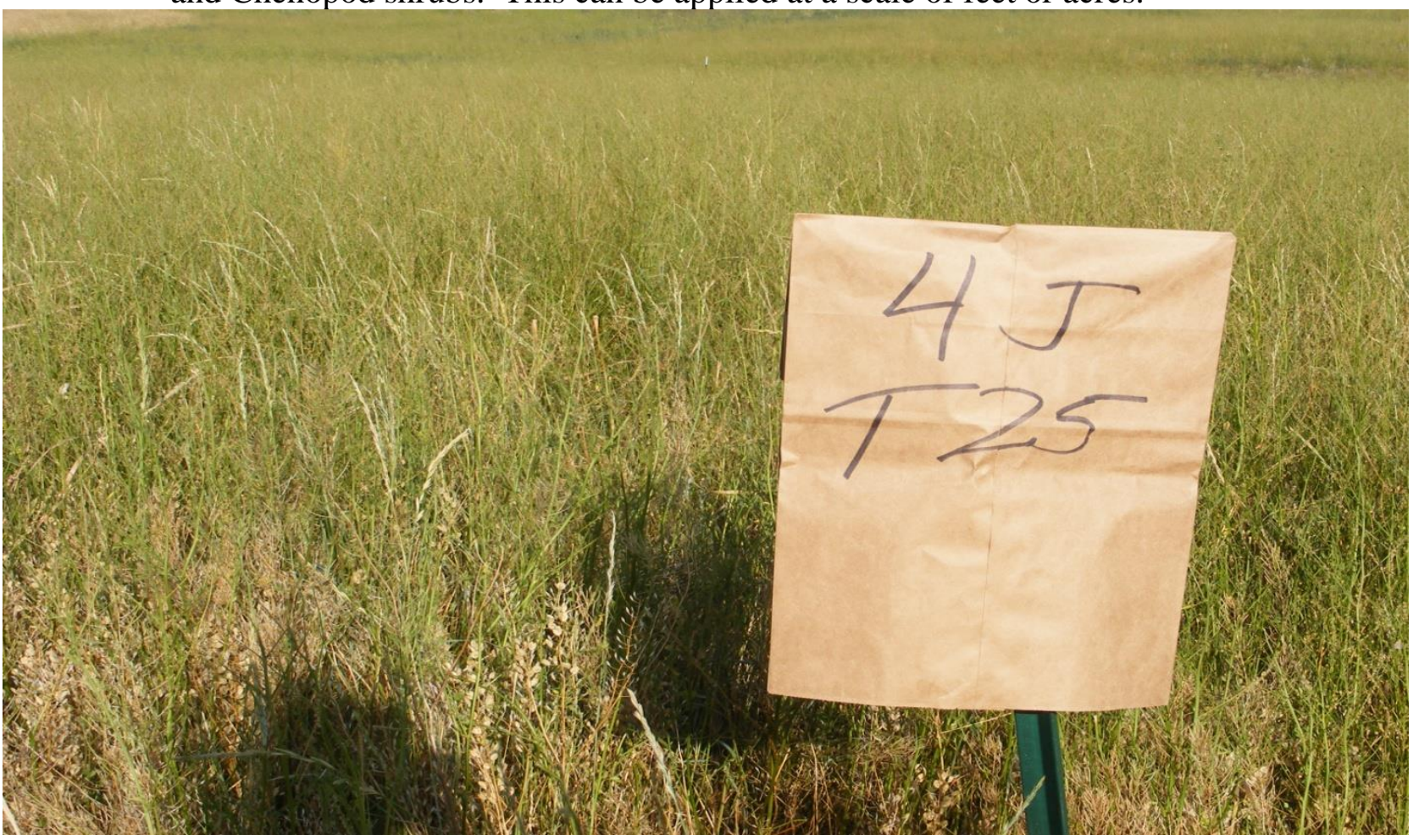

Figure 15. Big sagebrush has little chance of establishing in such a competitive environment despite being seeded at 12 pounds PLS/acre. 


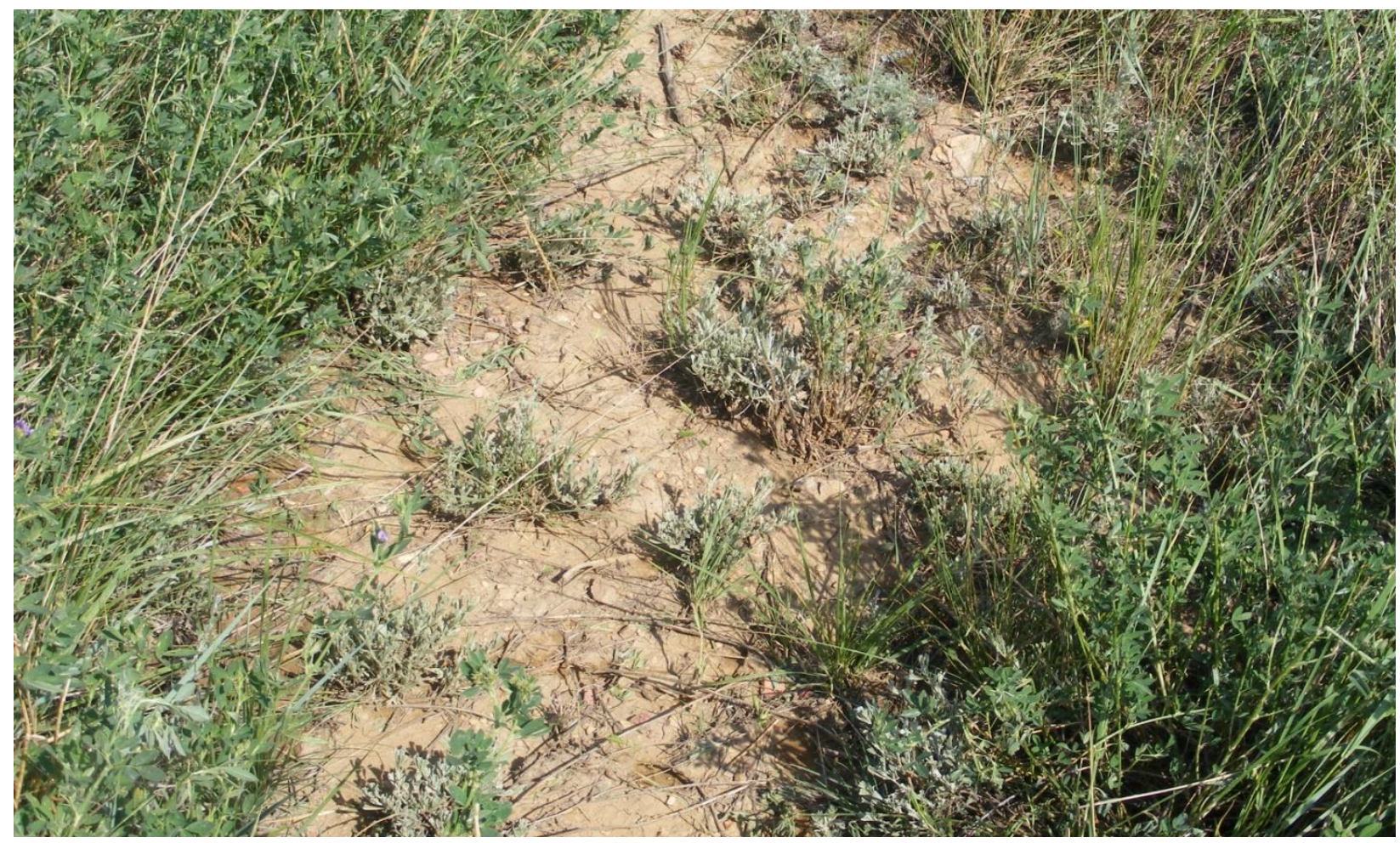

Figure 16. Small opening in drill-seeded topsoil provided good habitat for broadcast sagebrush seed at SCCM field PAR 6D seeded 4/10 and photographed 6/15. Big sagebrush grows slowly.

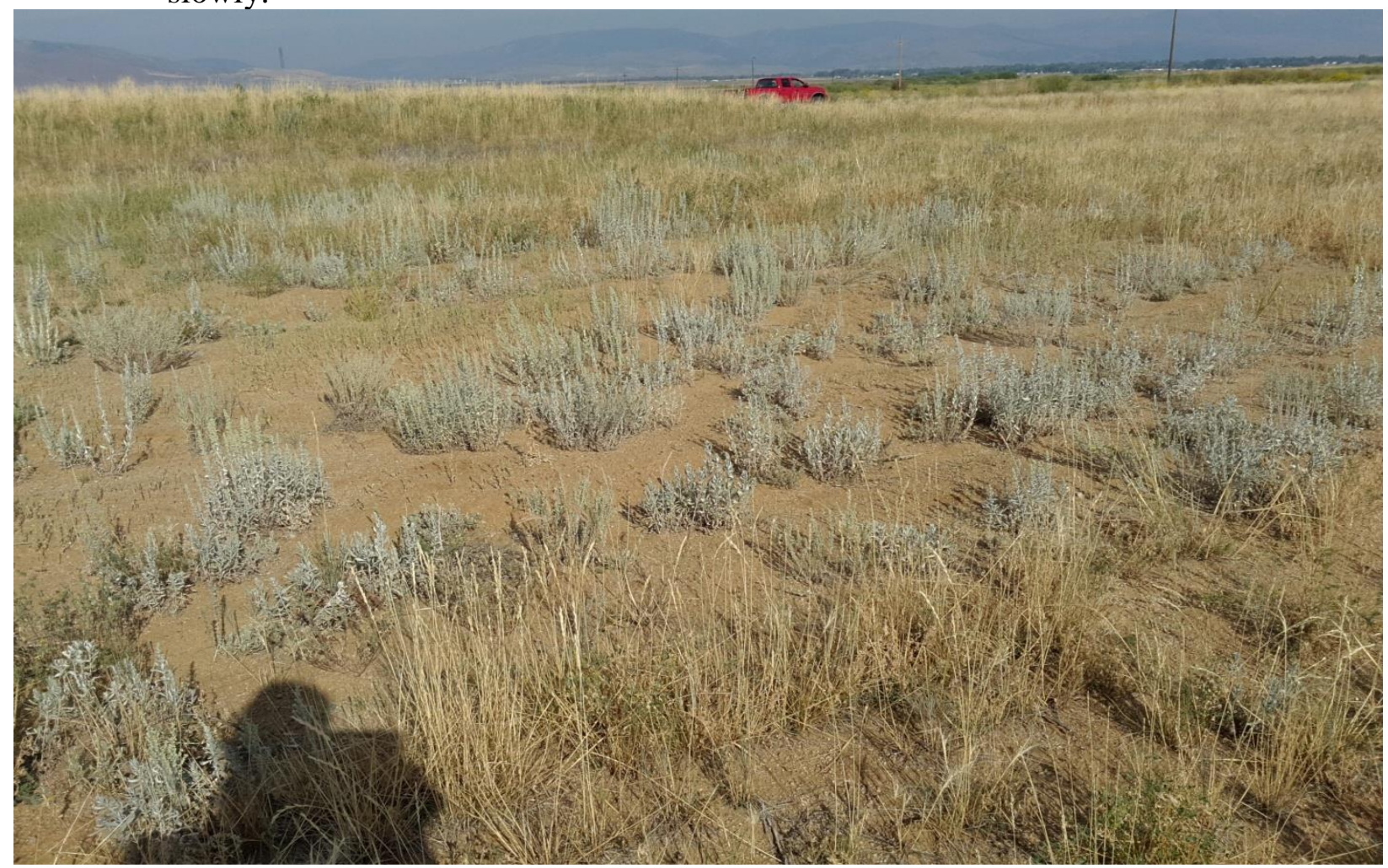

Figure 17. Here the light seed, mid-ground, was seeded apart from the heavy seed, background. 
JASMR, 2016 Volume 5 Issue 1
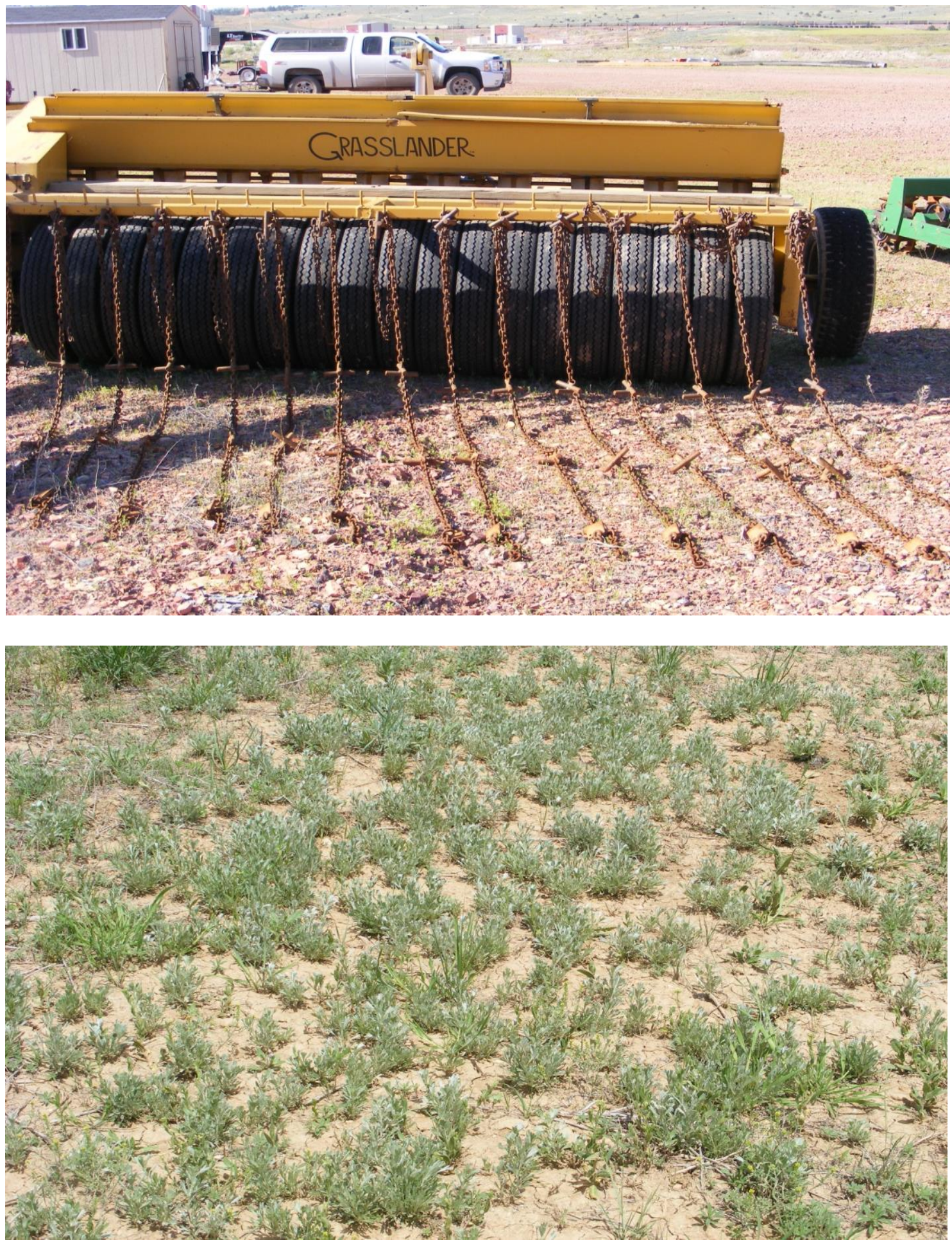

Figure 18. SCCM's Grasslander is a controlled broadcast seeder that drops seed down fourinch tubes followed by a bank of packer wheels and a chain harrow (top photo). Seeding nine pound PLS big sagebrush seed/acre - and nothing else - yielded the dense sagebrush in the lower photo. The cost for sagebrush seed alone exceeded $\$ 7,400 /$ ha $(\$ 3,000 /$ acre $)$. 


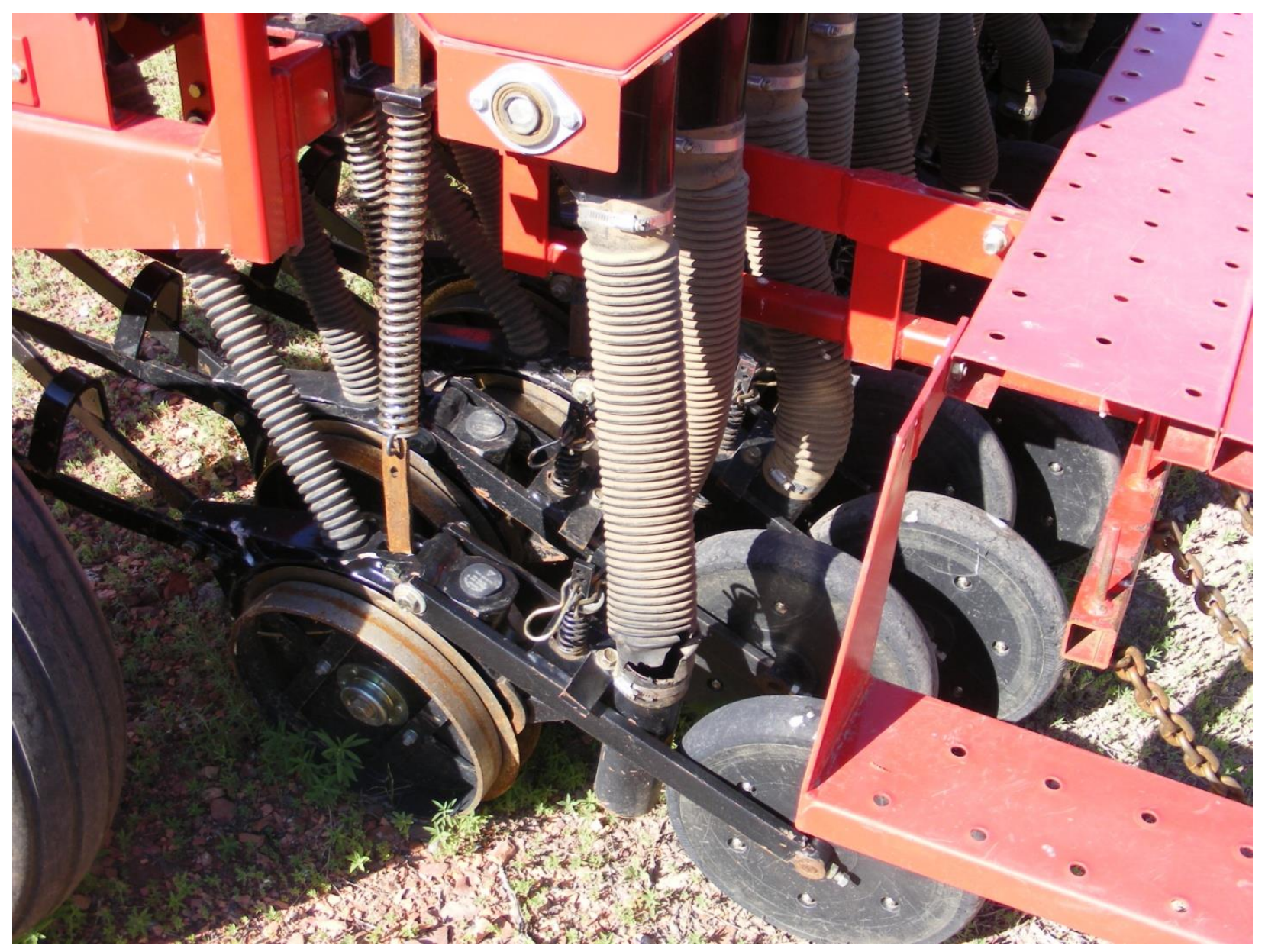

Figure 19. Drill seeder with legume box. The angled drill tubes, left, deliver the heavy seed to be placed in slits cut by preceding discs and followed by packer wheels. The big, vertical hoses, center, deliver light seed including sagebrush and rabbitbrush from the legume box, dropping it on the surface, where some is pressed by the packer wheels with other seed covered by a chain harrow. By blocking some drill tubes, only light seed is delivered to all portions of each seeded strip, but widely spaced rows of wheatgrasses and Chenopod shrubs provide assured cover, production, and some shrubs. This is one way to shield light-seeded shrubs from competition.

Foremost among annual weeds at the Decker-area mines is kochia. Kochia (Bassia scoparia formerly Kochia scoparia) is an annual Chenopod tumbleweed that has largely replaced the other first-wave weeds in fresh fields, Russian thistle and lambsquarter. Originally a weed of tilled fields in Montana, it has been present at SCCM since at least 1997 and was rampant at DCM by 2000. Kochia is adapted to harsh conditions, including alkaline soils, and can germinate whenever conditions are advantageous. Its genotype seems to be adapting to the mine environment, and kochia is ever a more serious weed in new fields. 
In a moist spring, kochia can form swards more than one meter tall (upper Fig. 20). Through interference competition for nutrients, soil moisture, and sunlight, it reduces perennial seedling density. Summer rains favor those surviving perennials, but spring rains promoting kochia followed by a dry summer have caused seeding failures. A combination of allelopathy and nitrogen depletion suppresses the second generation (lower Fig. 20), leaving a crop of standing litter that prevents inter-seeding in the absence of effective litter removal.

A typical early weed succession in a new field at both mines is kochia $\rightarrow$ tumblemustard $\rightarrow$ cheatgrass +- false flax or field pennycress (Fig. 21). Cheatgrass, then, is the final annual weed in the sequence, and we have seen that it can be persistent (Table 7). (But as noted earlier, western wheatgrass can replace annual weeds unassisted.)

Prevention is by far the most effective strategy. As tumbleweed, kochia must be controlled mine-wide, which is made difficult by the massive amount of earthmoving at coal mines. The worst possible scenario is to lay cover soil in the fall (whether seeded in fall or spring) so kochia tumbleweeds have months to blow across fresh dirt before germinating in spring (Fig. 22).

In contrast, spring soil laydown and prompt seeding means fewer annual weeds. Stockpiled soil, if not host to annual weeds, means fewer annual weeds than direct-haul. New fields in the western portion of the mines have noticeably less kochia because the general flow of tumbleweeds is toward the east.

SCCM has mowed first-year kochia fields with good results. Mowing must be timed early enough to release perennials and late enough to limit weed regrowth. But mowing can abruptly end when unseen rocks are struck. Parts must be ordered, the mower is a low-priority repair, and the result can be the end of mowing for that season. However, that doesn't mean that it's not worth the effort, including windrowing rocks during the topsoil laydown process so they are not struck when mowing.

SCCM recently bought a Weed Wipe ${ }^{\mathrm{TM}}$ to kill kochia towering over perennials (Fig. 23). The portion of kochia run over by tractor wheels goes untreated, and delivering the right amount of glyphosate to the roller wick requires experience, but it promises to be a better alternative than dealing with a litter-choked field with surviving perennials. 
JASMR, 2016 Volume 5 Issue 1
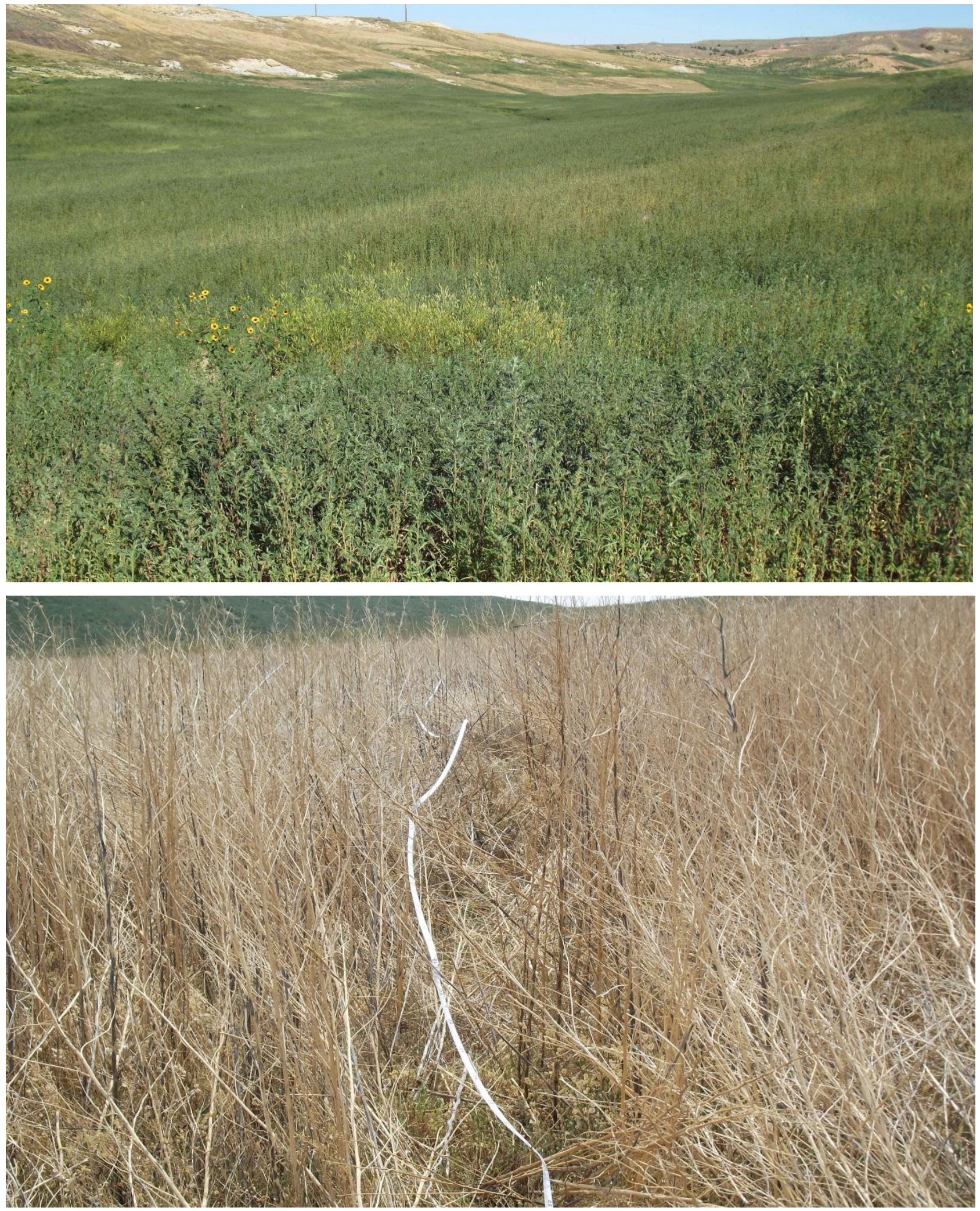

Figure 20. Kochia in DCM field D11u in 2012 following a fall 2011 seeding. Spring and annual precipitation was normal in 2012. Lower photo shows second-year kochia litter in field E13u; clearly, it is not seedable. 
JASMR, 2016 Volume 5 Issue 1

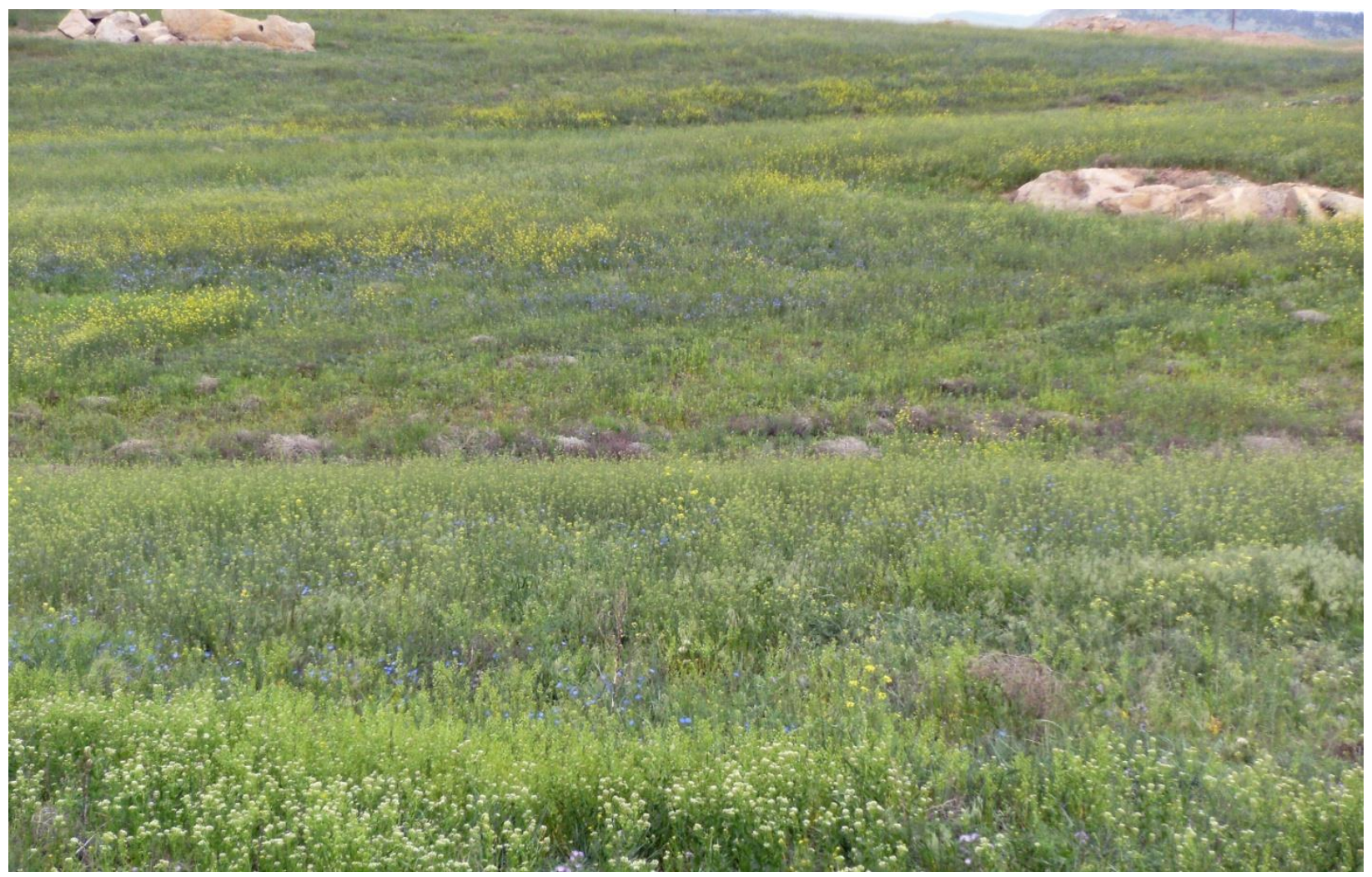

Figure 21. Collection of second-year weeds on topsoil: Thlaspi arvense (white flowers), Sisymbrium loeselii (yellow flowers) and, less conspicuously, green kochia and cheatgrass.

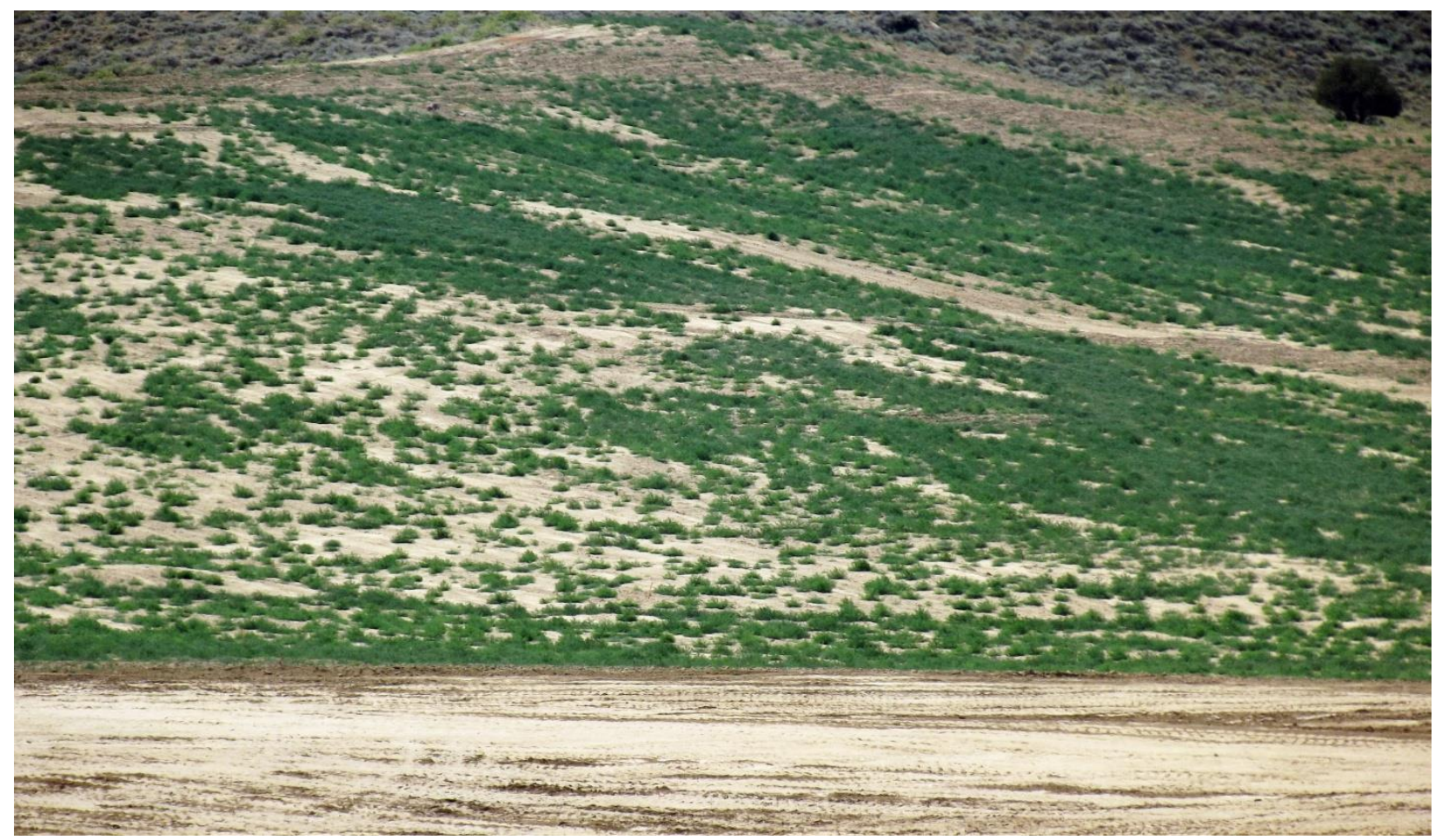

Figure 22. Unseeded field with kochia is sure to have even more annual weeds after seeding. 


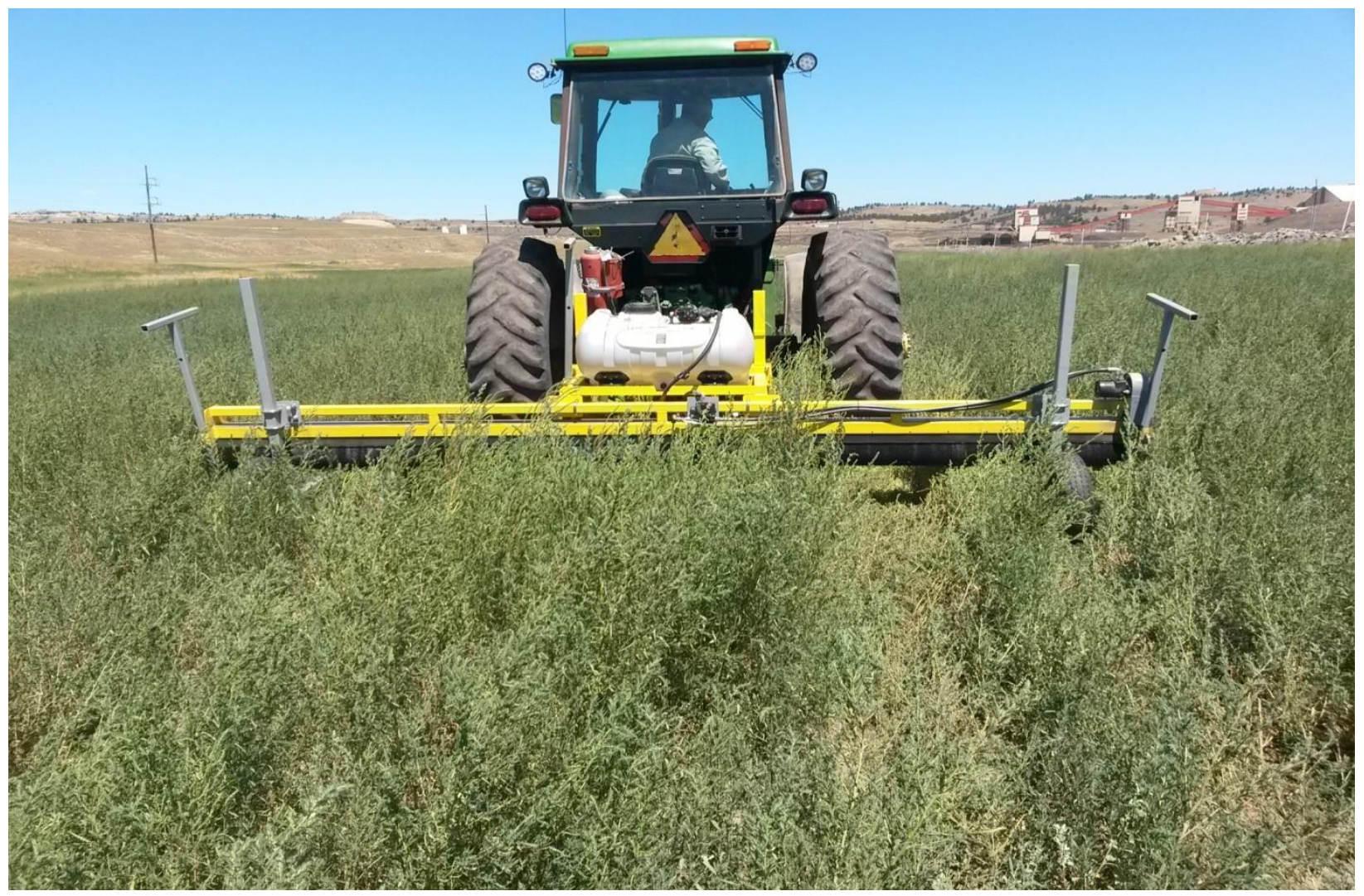

Figure 23. Applying glyphosate to tall kochia with a rotating wick applicator while sparing perennials beneath.

In a satisfactorily seeded field with perennial seedling density of $>1$ per square foot, the forb weeds soon disappear through a combination of auto-suppression and superior competitive ability of the perennials (and also perhaps nitrogen depletion). But in a poor seeding, the weeds can persist, presenting two big challenges, one from the quick-growing weeds themselves and one from the ensuing litter. Both must be overcome.

SCCM attempted many inter-seedings into weed patches. Broadcasting sagebrush and other light seeds never worked. The seed was hoped to germinate on the soil surface under the litter, where it would be protected from desiccation, but the fresh crop of annual weeds completely overwhelmed perennial seeds.

Drill seeding a vigorous mix of heavy-seeded species sometimes improves the field (Fig. 24), but only a portion of such attempts work. While heavy seeds are better equipped to establish among weeds, surface and aerial litter can prevent properly placing seed into the soil through accumulated litter. A receptive seedbed is extremely important. 
For the best chance of successful inter-seeding, weed seed on the ground must be prevented from germinating and the litter thatch removed so seed can be properly placed with good soil contact. A moldboard plow that inverts the dirt and buries weed seed might work, but SCCM doesn't have a moldboard plow, and powerful tractors are required to pull the current generation of plows quickly enough for them to flip the soil. Tilling out weeds requires repeated discing, allowing weeds to germinate, discing again, etc. This has never been tried because it would take so long in a semiarid climate to germinate multiple generations of weeds. An additional dust source on mines is another issue, and tumbleweeds would likely provide a perpetual supply of fresh weed seed.

At DCM, burning the litter prior to seeding has worked (Fig. 25), but eventually a fire got away, and that cooled the passion for burning, even though the fire did not spread outside revegetation and did not damage revegetation. Surface mines have the equipment to build fire lines and respond to fires that escape, but there is a general reluctance to burn. Visibility for mine traffic and the possibility of shrub stands in revegetation catching fire are two valid reservations about burning. Regarding litter, SCCM is currently working on a drag that loosens the litter so it blows away.

The second problem is that weed seed dominates the seedbank, or weeds may be growing when seeding is desired. Even "no-till" seeding disturbs the soil surface enough to initiate a new crop of annual weeds. Herbicides are a critical step to effectively seeding weed patches.

A fall or early spring application of a pre-emergent herbicide persistently suppresses annual weeds for more than one year. DCM has experimented with Plateau ${ }^{\mathrm{TM}}$, and it can be stunningly effective in temporarily eliminating cheatgrass and annual forbs (Fig. 26). Apply in fall, or, if necessary, early spring. If a fresh crop of weeds has germinated in spring and a pre-emergent herbicide application is still desired at that time, it can be mixed with a complementary foliar herbicide. Seeding must be delayed one entire growing seasons so the chemicals don't impair perennial seedling establishment, especially the shrub and forb component.

Fall Plateau application at DCM also has reduced plant litter the following year to such an extent that some fields can be seeded without further liter removal measures (lower Fig. 26), but more often further litter reduction is required prior to seeding. 
JASMR, 2016 Volume 5 Issue 1

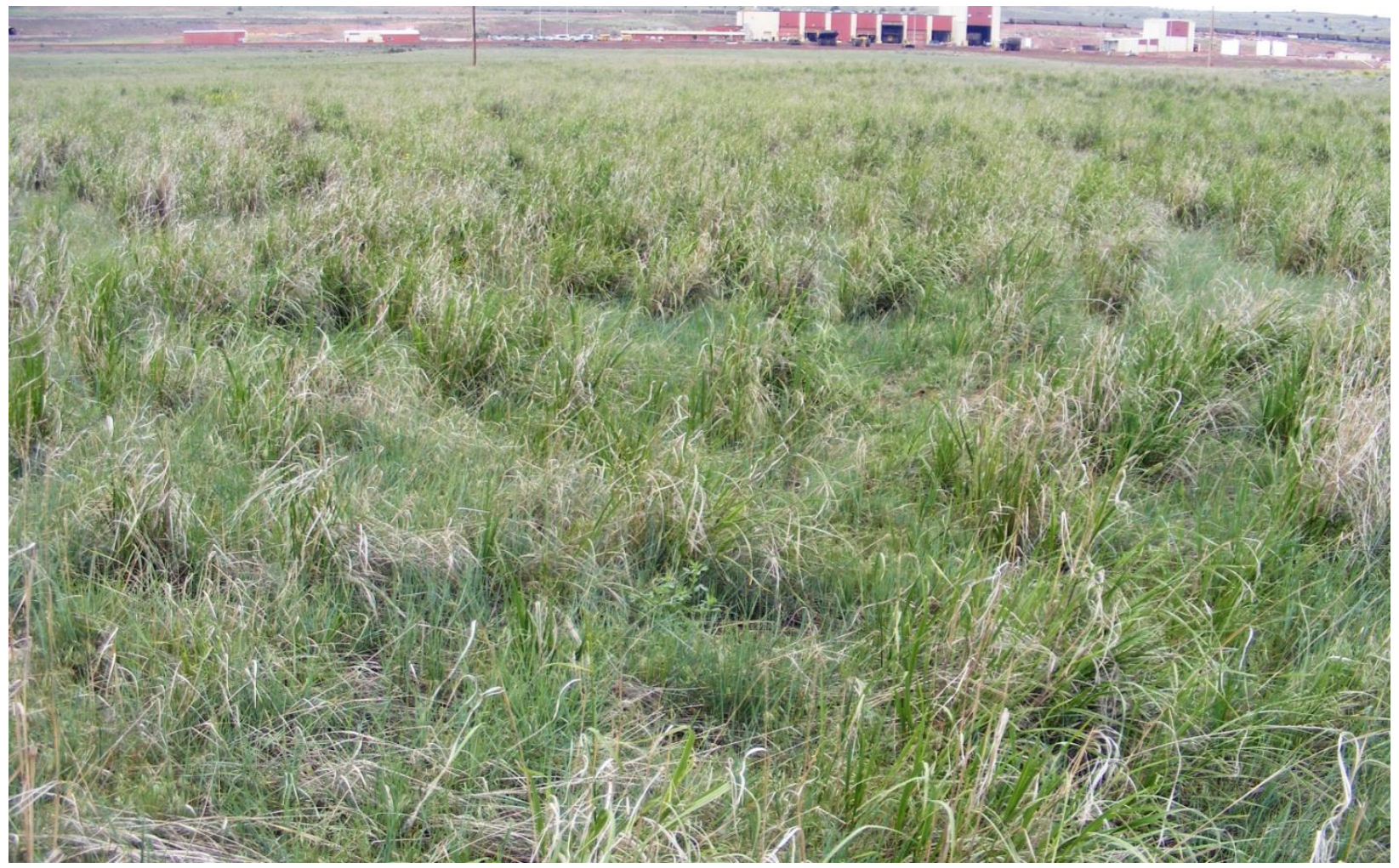

Figure 24. Almost all of SCCM fields were inter-seeded five years after the initial seeding (11/08) due to persistent weedy condition. This 2015 photo shows a good field of grass but few shrubs.

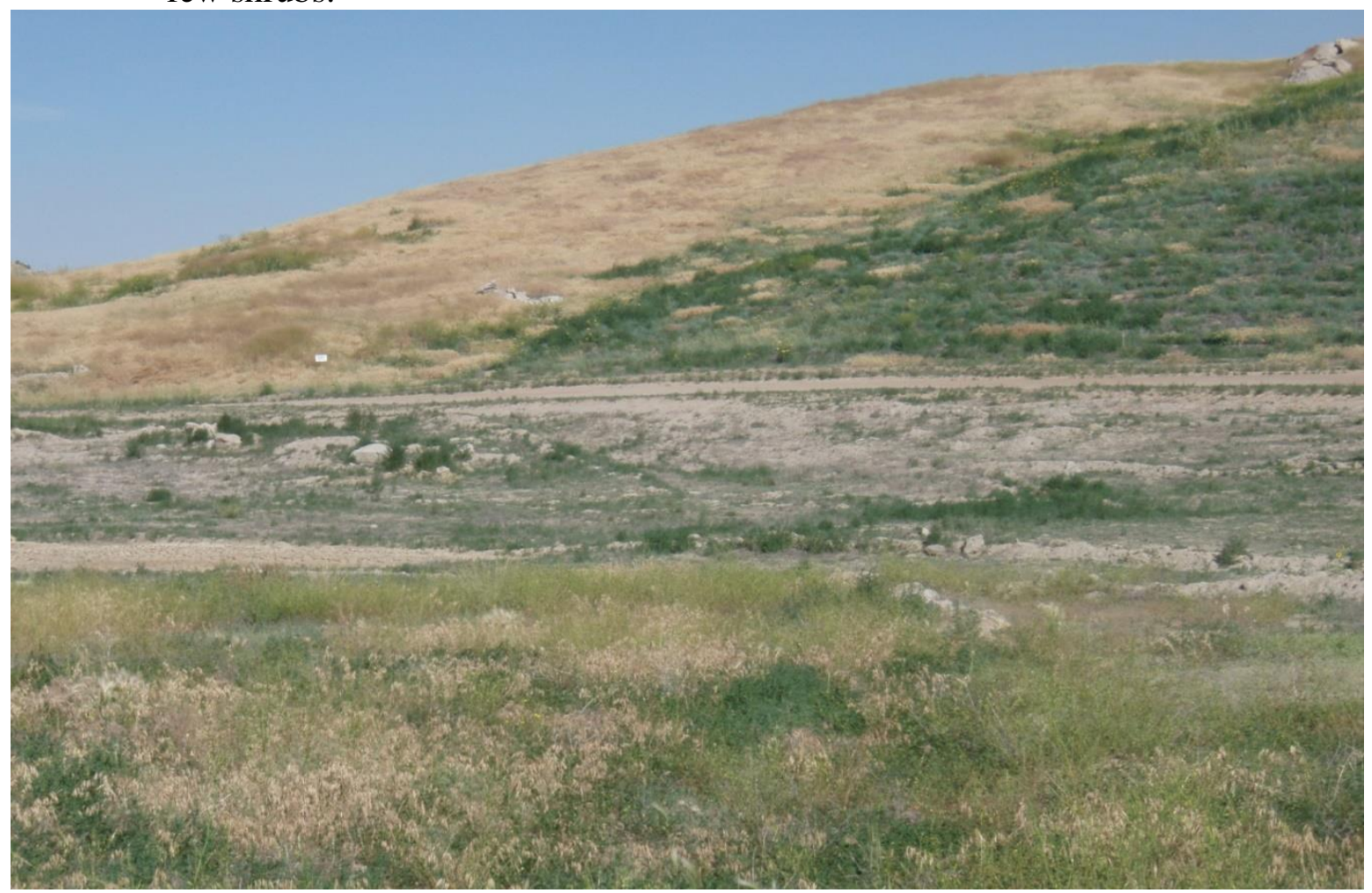

Figure 25. Unburned persistent cheatgrass left. Upper right was burned and seeded. 
JASMR, 2016 Volume 5 Issue 1
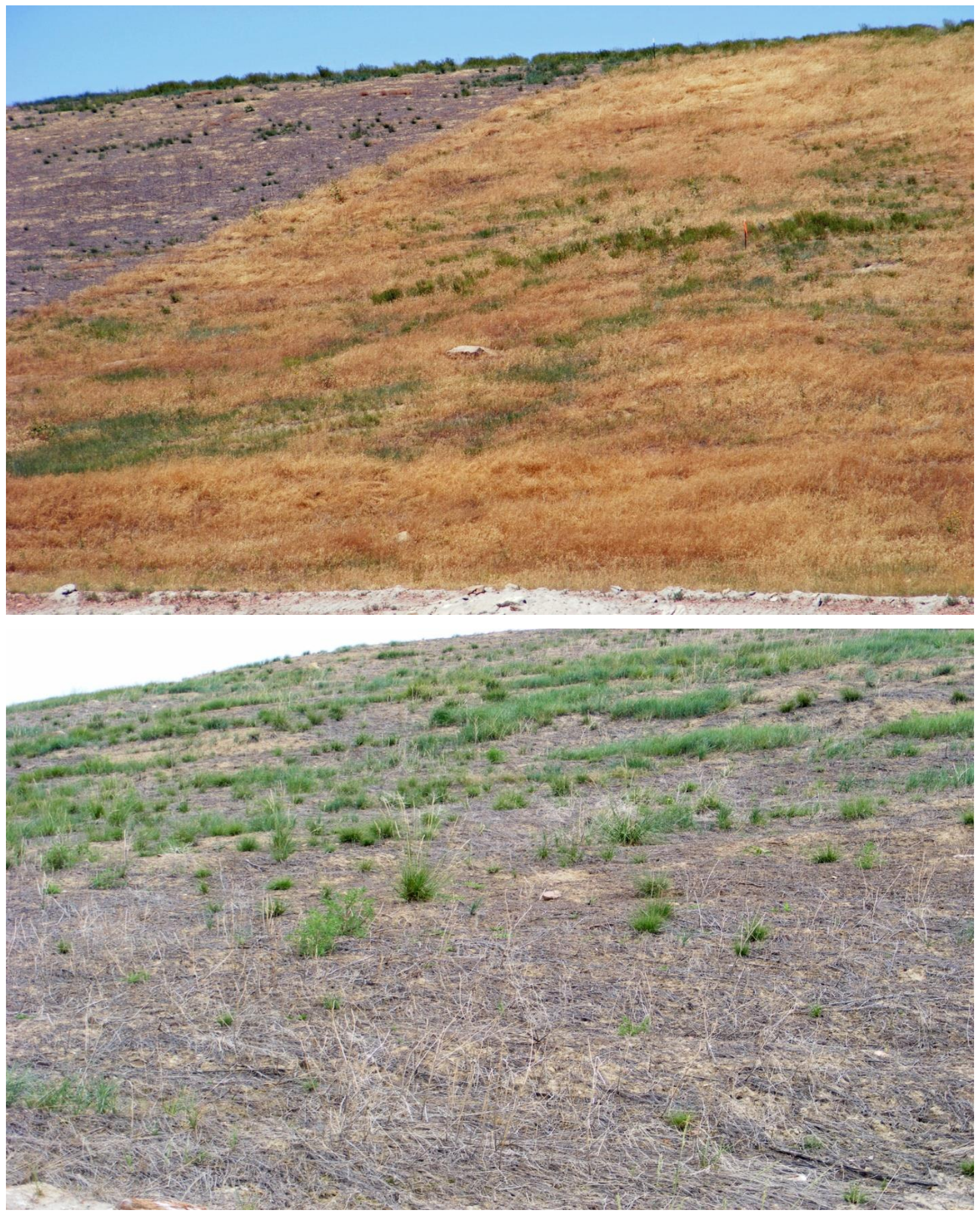

Figure 26. DCM field treated with Plateau (upper left) and untreated adjacent area - mostly weeds with some western wheatgrass. Lower photo shows that further litter removal is unnecessary for seeding. Established grass is western wheatgrass, and it is spreading. 
A last-ditch alternative is to bury the weeds with additional cover soil. Fantastically expensive, this does point up the importance of capitalizing on the fresh seedbed, of not introducing weeds with the cover soil, and of mine-wide management of tumbleweeds. Sometimes one fervently wishes to have that fresh soil back, and this time to do everything right.

\section{Summary}

The two Montana coal mines providing the trends and lessons presented here find that meeting cover and production standards for the two dominant post-mine land uses, grazing land and wildlife habitat, are achievable. Meeting shrub-density standards, especially for wildlife habitat, has so far not been consistently achieved. This is exacerbated by the decreasing shrub-density temporal trend.

The heavy-seeded Chenopod shrubs can establish from drill-seeding among the all-star revegetation species in any substrate. For all shrubs, but especially sagebrush, substrate is a key element influencing shrub establishment. The right spoil can be fine shrub habitat, poor weed habitat, and suitable grass habitat. It remains for the mines to quantify the constituent properties of good spoil. Scoria can also be good shrub habitat, but DCM has had more successes than SCM, although the latter has seeded as much scoria. Scoria properties haven't been evaluated relative to shrub suitability.

Another key to sagebrush establishment is providing a relatively competition-free setting, sagebrush being a stress-tolerate rather than a competitor (Grime, 1979). Sagebrush seed must be placed very near the surface but with good soil contact. The best seedings, through spatial segregation, provide both adequate shrub density and cover production.

While first-year Chenopod annuals such as Russian thistle and lambsquarter have long attended western revegetation, kochia can be far more deleterious to desired perennials. Prevention can be largely effective, but it takes mine-wide diligence. First-year herbicide application that kills overtopping kochia, while sparing the smaller perennials, can save a seeding. While kochia auto-suppresses the second year, seeding activity promotes a fresh crop. A preemergent herbicide provides a fallow condition for one year, after which spring seeding can largely avoid the negative consequences of kochia infestation. 
JASMR, 2016 Volume 5 Issue 1

\section{$\underline{\text { List of Common and Scientific Plant Names }}$}

Common Name

Big sagebrush, Wyoming

Black greasewood

Cheatgrass

False boneset

Hairy false goldenaster

Kochia

Lambsquarter

Prairie milkvetch

Prickly rose

Rubber rabbitbrush

Russian thistle

White locoweed

Sheep fescue

Silver sagebrush

Winterfat
Scientific Binomial

Artemisia tridentata ssp. wyomingensis

Sarcobatus vermiculatus

Bromus tectorum including B. arvensis

Brickellia eupatorioides

Heterotheca villosa

Bassia scoparia

Chenopodium album

Astragalus adsurgens

Rosa acicularis

Chrysothamnus nauseosus

Salsola kali

Oxytropis sericea

Festuca ovina complex var. covar

Artemisia cana

Krascheninnikovia lanata

\section{Literature Cited}

Daubenmire, R. 1959. A canopy-coverage method of vegetational analysis. Northwest Sci. 33(1): pp 43-64.

Grime, J.P. 1979. Plant strategies and vegetation processes. Wiley, N.Y. 222 pp.

Montana Department of Environmental Quality. 2015. Annual Report. Permitting and Compliance Division, Industrial and Energy Minerals Bureau, Coal and Uranium Program. Information through June 30, 2015

Prodgers, R. 2013. Fitness more than diversity guides vegetational recovery. Journal American Society of Mining and Reclamation, 2013 Volume 2, Issue 2 pp 113-141. http://dx.doi.org/10.21000/JASMR13020113 